The "Squeaky Wheel" Gets No Grease: Persisting Problems at the Interface of the Mental Health and the Criminal Justice Systems

By Krista Lazette

A thesis submitted to the Faculty of Graduate Studies and Research

In partial fulfillment of

The requirements for the degree of

Master of Arts

Department of Law

Carleton University

Ottawa, Ontario

April 8, 2007

(C) 2007, Krista Lazette 


$\begin{array}{ll}\begin{array}{l}\text { Library and } \\ \text { Archives Canada }\end{array} & \begin{array}{l}\text { Bibliothèque et } \\ \text { Archives Canada }\end{array} \\ \begin{array}{l}\text { Published Heritage } \\ \text { Branch }\end{array} & \begin{array}{l}\text { Direction du } \\ \text { Patrimoine de l'édition }\end{array} \\ \begin{array}{l}\text { 395 Wellington Street } \\ \text { Ottawa ON K1A ON4 } \\ \text { Canada }\end{array} & \begin{array}{l}\text { 395, rue Wellington } \\ \text { Ottawa ON K1A 0N4 } \\ \text { Canada }\end{array}\end{array}$

Yourfile Votre référence ISBN: 978-0-494-26956-5 Ourfile Notre référence ISBN: 978-0-494-26956-5

NOTICE:

The author has granted a nonexclusive license allowing Library and Archives Canada to reproduce, publish, archive, preserve, conserve, communicate to the public by telecommunication or on the Internet, loan, distribute and sell theses worldwide, for commercial or noncommercial purposes, in microform, paper, electronic and/or any other formats.

The author retains copyright ownership and moral rights in this thesis. Neither the thesis nor substantial extracts from it may be printed or otherwise reproduced without the author's permission.
AVIS:

L'auteur a accordé une licence non exclusive permettant à la Bibliothèque et Archives Canada de reproduire, publier, archiver, sauvegarder, conserver, transmettre au public par télécommunication ou par l'Internet, prêter, distribuer et vendre des thèses partout dans le monde, à des fins commerciales ou autres, sur support microforme, papier, électronique et/ou autres formats.

L'auteur conserve la propriété du droit d'auteur et des droits moraux qui protège cette thèse. $\mathrm{Ni}$ la thèse ni des extraits substantiels de celle-ci ne doivent être imprimés ou autrement reproduits sans son autorisation.
In compliance with the Canadian

Privacy Act some supporting forms may have been removed from this thesis.

While these forms may be included in the document page count, their removal does not represent any loss of content from the thesis.
Conformément à la loi canadienne sur la protection de la vie privée, quelques formulaires secondaires ont été enlevés de cette thèse.

Bien que ces formulaires aient inclus dans la pagination, il n'y aura aucun contenu manquant.

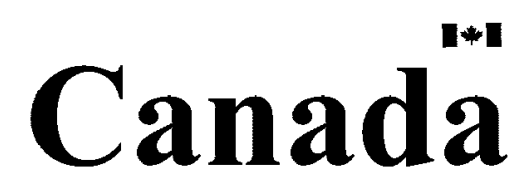




\begin{abstract}
The history of providing care to individuals suffering from mental illness in Canada is one that is complex and often controversial. Through an exploration of current practices concerning mentally ill offenders in the Ottawa region I argue that individuals awaiting an assessment of their fitness or criminal responsibility are unconstitutionally detained. Many critics, including lawyers and other members of the justice system, mental health agencies, families, and Members of Parliament, argue that this specific problem facing accused mentally ill individuals is a result of insufficient funding and resources and contend that in order to resolve the issue the Ontario government must implement the necessary funding to provide for more forensic assessment beds and services. I argue that this problem is much more complex and goes beyond issues of funding. We can better understand this problem by locating the unconstitutional detention of mentally ill individuals within broader social, political and economic contexts which shape the mental health and justice system's practices of responding to this specialized group of offenders.
\end{abstract}




\section{Acknowledgements}

It has been a privilege to be able to work with Professor Dawn Moore and Professor Diana Young as my advisers. I would like to thank Prof. Dawn Moore for all of her advice and support over the past two years. Through her guidance I was able to pursue and complete a project of great importance to me. I would also like to extend my appreciation to Prof. Diana Young as my second advisor.

I would like to thank my employer, and friend, Heather Perkins-McVey for her support throughout my academic career. I appreciate your time and commitment to seeing me through all the challenges I have been presented with thus far.

I would like to express a final word of thanks to each of the individuals who participated in this research project. 


\section{Table of Contents}

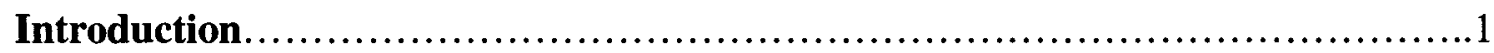

I. Deinstitutionalization....................................................

- Introduction

- Deinstitutionalization

- Negative Research Findings and Changing Public Opinion

- Development of Psychotropic Drugs

- Implications for Poorly Implementing Deinstitutionalization

- Conclusion

II. Responsibilizing the Mentally Ill Offender.

- Introduction

- The Rhetoric of Action

- Identifying the Mentally Disordered Offender

- Assessment Orders

- Outcry for Government Support

- Conclusion

III. Jailing the Mentally Ill Unconstitutional: R v. Hussein \& Dwornik .59

- Introduction

- $R$ v. Hussein \& Dwornik

- Prerogative Remedies for Mentally Ill Offenders

- The Need for Government Support

- Conclusion

IV. Moving Forward: Difficult Decisions Regarding Mentally Ill Offenders.

- Phaneuf v. Her Majesty the Queen in Right of Ontario

- $R v$. Rosete: Can Detention be Justified?

- Conclusion

Conclusion .95

Bibliography ............................................................. 98

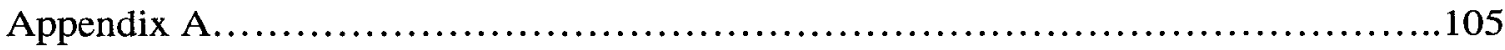

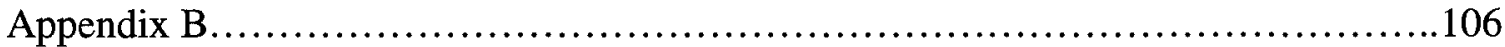

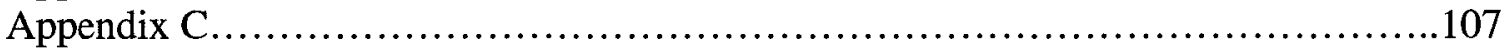

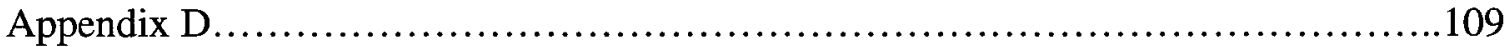

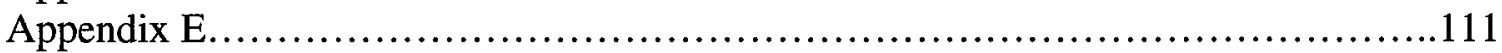

Appendix F................................................................ 112

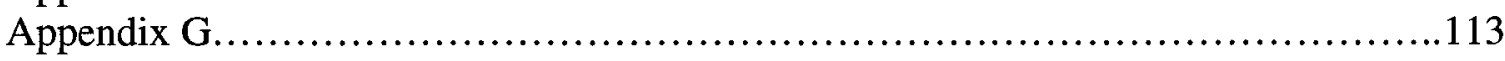




\section{List of Tables}

Table 1.1. Rated Bed Capacity of Operating Institutions by Province 1965 to $1980 / 1981$

Table 2.1 A Comparison of the Legislative Changes Before and After the Implementation of Bill C-30 .43

Table 3.1 Bed Registry Vacancy Screen.........................................72

Chart 4.1 Duration of Time Spent in Custody Awaiting a Psychiatric Assessment......81 


\section{List of Illustrations}

Chart 4.1 Duration of Time Spent in Custody Awaiting an Assessment.................83 


\section{List of Appendices}

$\begin{array}{ll}\text { Appendix A: List of Acronyms } & 105\end{array}$

Appendix B: List of Interviews 106

Appendix C: Informed Consent Form 107

$\begin{array}{ll}\text { Appendix D: Letter of Information } & 109\end{array}$

Appendix E: Form $48 \quad 111$

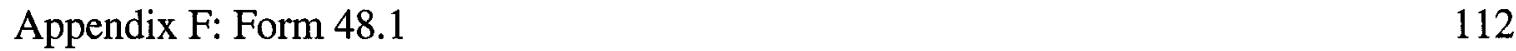

Appendix G: List of Questions 113 


\section{Introduction}

In 2004 one Ontario Superior Court judge declared the practice of detaining accused individuals awaiting a psychiatric assessment in a designated hospital unconstitutional and ordered the Ontario Government to make swift changes within six months of his decision to rectify the problem. Through an exploration of the current practices concerning mentally ill offenders in the Ottawa region, I argue that individuals awaiting an assessment of their fitness or criminal responsibility continue to be unconstitutionally detained. Many critics, including lawyers and other members of the justice system, mental health agencies, families, and Members of Parliament, argue that this specific problem facing accused mentally ill individuals is a result of insufficient funding and resources. These groups contend that in order to resolve the issue the Ontario government must implement the necessary funding to provide for more forensic assessment beds and services. I argue that this problem is much more complex and goes beyond issues of funding. We can better understand this problem by locating the unconstitutional detention of mentally ill individuals within broader social, political and economic contexts which shape the mental health and justice system's practices of responding to this specialized group of offenders.

While working alongside an Ottawa criminal defence lawyer I have witnessed several mentally ill individuals having to be detained in jail while awaiting an in-custody psychiatric assessment at the Royal Ottawa Mental Health Centre (ROMHC). ${ }^{1}$ Some of these individuals have been charged with minor offences and may have never encountered the criminal justice system. In some cases, individuals who are presumed to

\footnotetext{
${ }^{1}$ The Royal Ottawa Hospital closed in October of 2006 and patients were transferred to the new hospital, now known as the Royal Ottawa Mental Health Centre. Both names will be used throughout this paper depending on the timeline I am referring to.
} 
be innocent may spend more time in custody waiting for the assessment than they would have received had they entered an early plea of guilt. ${ }^{2}$ Given their mental instability and need for psychiatric treatment, the hardships of custody are exacerbated for individuals suffering from mental health problems. Recently, the lack of available resources at the interface of the criminal justice and mental health systems has come to the attention of Canada's criminal courts, who have directed the Ontario Government to respond to this specialized group of offenders. ${ }^{3}$

The history of providing care to individuals suffering from mental illness in Canada is one that is complex and often controversial. The institutionalization, and later deinstitutionalization of mentally ill individuals here, and in other Western jurisdictions can be best understood by considering the legislative, political and economic changes occurring between the mid to late 1800 s and post WWII era. I have selected this time period because it encompasses these two important shifts impacting mentally ill individuals, as well as reflecting changing political and social perspectives. Although most agree that the movement of mentally ill individuals into the community was intended to provide a more humane form of treatment, the way in which deinstitutionalization was implemented is possibly one of the most problematic issues in mental health. Beginning in the early 1960s a number of competing interests, including those of academics, civil libertarians, pharmaceutical companies, physicians, and government, came together and collectively argued for the transfer of mentally ill individuals from psychiatric institutions to a network of community housing and services. Those in support of a more humane form of treatment cited the failure of asylums to cure

\footnotetext{
${ }^{2} \underline{R}$ v. Hussein and Dwornik [2004] 191 C.C.C. (3d) 113 para 5 (O.S.C.J)

${ }^{3} \underline{\text { Ibid. }}$ at para 6.
} 
individuals suffering from mental illness and highlighted the importance of family and the community as strong social supports. ${ }^{4}$ Others suggest that advocates such as government, and pharmaceutical companies, were largely influenced by personal economic gains. ${ }^{5}$ Drug companies argued that the new development of psychotropic drugs in the 1950s would enable mentally ill individuals to successfully manage the symptoms of their illnesses in the community. Furthermore, financial gains were realized by the government when the Canada Assistance Plan was implemented in 1966 which enabled the province to claim 50 percent of the costs of patients who were moved from provincial hospitals into the community. ${ }^{6}$

Regardless of their initiatives for supporting the movement, studies conducted over the past twenty-five years have identified a number of positive outcomes associated with community based treatment and care for the mentally ill. As a result, many individuals support the movement of deinstitutionalization and often attribute any negative consequences of this shift to insufficient funding or a lack of community resources. One such example can be illustrated by the problems presented at the interface of the criminal justice and mental health systems. After being charged with a criminal offence many individuals suffering from mental health problems are ordered by the court to undergo an assessment of their mental condition pursuant to section 672.11 of the Criminal Code of Canada. Often, however, hospitals do not have space available to accommodate such individuals. A practice has evolved in Ottawa, and other parts of the

\footnotetext{
${ }^{4}$ D. Rothman, The Discovery of the Asylum (Boston: Little Brown, 1971) and E. Goffman, Asylums (Chicago: Aldine Publishing Company, 1961).

${ }^{5}$ R. Lamb, \& L. Weinberger, Deinstitutionalization: Promises and Problems (San Francisco: John Wiley \& Sons Inc., 1994) at 3.

${ }^{6}$ L. Bachrach, "Deinstitutionalization: What Does it Really Mean?" (1994) Schizophrenia: Exploring the Spectrum of Psychosis.
} 
province, whereby individuals are detained in custody until a bed becomes available at a designated hospital. In the 2004 case of $R v$. Hussein and Dwornik Justice Desmarais declared this practice unconstitutional and directed the Ontario government to make swift changes to rectify the problem within six months of his decision. Since the decision was handed down in 2004, no substantive changes have occurred.

Although the movement of mentally ill individuals into the community began during the 1960 s one must consider that a clear policy framework supporting this shift was not developed in Canada until the early 1980s. As a result, an analysis of the impacts of deinstitutionalization must be regarded as a process, rather than an isolated event. It is also imperative to understand that the implementation of this movement involves variations both intra and inter provincially. Furthermore, one must consider other political, social and economic changes occurring during this time which have also impacted the treatment of mentally ill offenders. The issues highlighted in a number of recent cases enable us to recognize the magnitude of the problem facing accused mentally ill and provide us with the opportunity to review our current practices and policies for dealing with this specialized group of offenders. It is also apparent that there is a need to re-evaluate our expectations of the services that the criminal justice system may offer since it is also being used to access mental health services that are otherwise unavailable. Within this paper I will provide a comprehensive account of the institutionalization and deinstitutionalization movements in Canada and the broader socio-legal conditions which have led to the unconstitutional detention of mentally ill individuals at the interface of the mental health and justice systems. 


\section{Research Focus}

Through an exploration of current practices concerning mentally ill offenders in the Ottawa region I argue that individuals awaiting an assessment of their fitness or criminal responsibility are unconstitutionally detained. By locating this problem within broader social, political, and economic contexts I show that the treatment of the mentally ill runs parallel to larger movements in health and correctional practices. In this paper I will examine a number of diverse and often competing interests, including those of academics, civil libertarians, pharmaceutical companies, physicians, and government. In order to better understand the problems facing accused mentally ill awaiting a psychiatric assessment I must identify the political, economic and legal contexts in which these problems are occurring.

\section{Key Concepts and Terms}

The term "mental illness" is used repeatedly. For the purposes of this thesis I will adopt the definition of mental illness utilized by the Canadian Mental Health Association (CMHA) which refers to a "variety of mental disorders that can be diagnosed. Mental disorders are health conditions that are characterized by alternations in thinking, mood, or behavior (or some combination thereof) associated with distress and/or impaired functioning."7

\section{Methodology}

I conducted semi-structured interviews from October to December 2006 with five individuals working within the criminal justice and mental health fields (See Appendix B). The interviewees were non-random and non-representative. Some of the individuals

\footnotetext{
${ }^{7}$ Canadian Mental Health Association online: at < http://www.cmha.ca/bins/content_page.asp?cid=440\&lang=1\#mentalillness $>$.
} 
were selected strategically as I was aware of their involvement in working with accused mentally ill. Other interviewees were recommended by individuals within the sample who were aware of others knowledge within the area of mental health and criminal law. Each of the interviewees deal with accused mentally ill individuals either directly or indirectly while working within their professional capacity. Those who were interviewed can be sub-divided into three different categories: a member of the Ontario Ministry of Health and Long-term Care, members of the legal system, and lastly individuals working in the health system. It should be noted that this is not a representative sample.

Before interviews were conducted all interviewees were mailed, or faxed if previously agreed to, a detailed letter of information and a consent form (See Appendix C and D). The letter of information and the consent form outlined the essence of the interview, the duration of the interview and the risks involved. Once I obtained the individuals consent to voluntarily participate in my research project, I conducted the interviews. The interviews all took place in Ottawa over the telephone, or in person.

Interview questions revolved around the interviewee's experiences and their roles in working directly or indirectly with mentally ill individuals involved with the criminal justice system (See Appendix G). During the interviews we discussed some of the challenges both the criminal justice and mental health systems face when responding to the needs of accused mentally ill and their perceptions of the most viable and effective approaches for responding to this specialized group of offenders.

Detailed notes were taken throughout each of the interviews. Questions were open-ended, allowing for more variation and room to explore certain issues. As a result, the length of interviews ranged from approximately 1 to 2 hours. Once the interviews 
were transcribed, key themes were identified and will be discussed throughout Chapters 2,3 and 4.

All aspects of this project involving research with human beings were presented to and approved by the Ethical Research Review Board of Carleton University.

\section{Overview of Chapters}

Chapter 1 explores the history of institutionalization and deinstitutionalization of mentally ill individuals throughout the 1890 s to 1970 s amongst a backdrop of political legal and economic developments to provide the reader with the context in which the problems associated with the movement are occurring.

Chapter 2 reviews the literature on changes in punishment and contends that although theorists argue that we have moved into a neoliberal state, welfarist approaches are omnipresent within the criminal justice system today. In addition, I illustrate that what happens at the level of rhetoric does not always take place in practice. This Chapter then draws the reader's attention to one very specific problem occurring at the interface of the mental health and criminal justice systems.

Chapter 3 highlights Justice Desmarais' recognition of the practice which has developed whereby mentally ill individuals are detained in custody awaiting a psychiatric assessment in violation of their Charter rights and outlines the direction provided to the Ontario government to rectify the problem. In this Chapter it becomes apparent that Ontario Court judges are still operating under welfarist ideals while proposing solutions to this problem without considering the availability of resources. 
Chapter 4 discusses the legal attention directed towards resolving the problem facing accused mentally ill individuals but recognizes that the underlying problem cannot be resolved without paying attention to broader social, political and economic changes. 


\section{Chapter 1: Deinstitutionalization}

\section{Introduction}

The history of providing care to individuals suffering from mental illness in Canada has been a long and arguably ineffective one. Here, and in other Western jurisdictions, the institutionalization, and later, deinstitutionalization of the mentally ill can be best understood by considering the legislative, political and economic changes occurring between the mid to late 1800 s and 1970s. Within this chapter I will discuss how these changes have impacted two major shifts in Canadian history which in turn have affected the care of mentally ill individuals. The first of these shifts occurred in the 1800 s when the move to asylums was proposed to provide previously ostracized mental patients with shelter in institutional settings. The creation of asylums for mental patients is considered alongside the broader political changes impacting the move toward the welfare state. The second major shift began during the post WWII era during the later stages of welfarism ${ }^{8}$ when rehabilitation was the "hegemonic, organizing principle", and the state advocated for shared responsibility of control and order maintenance over problem populations. $^{9}$

The segregation and containment of other problem groups, such as lepers, established a practice that was later applied to the mentally ill. Individuals within the community asserted that leprosy was an infliction of both God's anger and of his grace. The church proclaimed that the abandonment of the leper would be the key to their

\footnotetext{
${ }^{8}$ For the purposes of this paper I will adopt the description of penal-welfarism set out by Garland (2001) to characterize the structure which combines the liberal legalism of due process and proportionate punishment with a correctionalist commitment to rehabilitation, welfare and criminological expertise.

${ }^{9}$ D. Garland, The Culture of Control (Chicago: University of Chicago Press, 2001) at 35.
} 
salvation. ${ }^{10}$ Lazar houses, which predated asylums, were used to segregate individuals suffering from leprosy to enable a clear division between those suffering at the hands of God's anger and grace, and those saved from disease. Foucault argued that although these structures prevented contagion, their purpose was not established on identifying a cure for the disease, but rather served to divide order from disorder. The lazar houses "were not founded on any project of cure; within their walls they enclosed a disordered world in which lepers were left to their own devices". 11 In time, the problem of leprosy disappeared but the associated structures of exclusion and division remained dormant within the Western culture. ${ }^{12}$

The practice of treating lepers and other problem populations enables one to recognize that there was a greater project of change occurring during the $19^{\text {th }}$ century. Pressure was placed on the government to remove troubled or nuisance populations from visible areas, like street corners, into isolated institutions. The containment of these individuals in "lazar houses" and "asylums" was justified by the government's pronounced public commitment to curing the individual of his disease. However, these structures failed to cure the individuals of their ailments, but rather served to alleviate political and social pressures placed on the government to remove problem populations from the eye of the public.

The second major shift began during the post WWII era in the 1950s and 1960s. The revitalized economy spurred the expansion of medical research and the rise of clinical experts within the field of mental health. The importance of research and

\footnotetext{
${ }^{10}$ M. Foucault, Madness and Civilization: A History of Insanity in the Age of Reason. (New York: Pantheon Books, 1965) at 7.

${ }^{11}$ M. Cousins, \& Athar Hussain. Michel Foucault (London: MacMillan Education Ltd., 1984) at 106.

${ }^{12}$ B. Smart, Michel Foucault (London: Routledge Press, 1991) at 20.
} 
specialization could also be seen more broadly during this period across disciplines, including in the area of penal reform and correctional practice. ${ }^{13}$ The movement towards a medical, or rehabilitative model of corrections in Canada attempted to turn the prison into a hospital and to treat the disease of criminality so that the criminal could be cured. ${ }^{14}$ MacNamara stated that this model "assumed the offender to be "sick" (physically, mentally and/or socially); his offence to be a manifestation or symptom of his illness, a cry for help...early acute diagnosis, followed by prompt and effective therapeutic interventions assured as affirmative prognosis - rehabilitation". ${ }^{15}$

During this time asylums came under attack from political and reformist sources which were supported by several social-scientific studies, such as that of Erving Goffman. Goffman's research on asylums in the United States illustrates the negative effects of being treated as a mental hospital patient. He found that the "uniform status of the mental patient serves to ensure an aggregate of persons a common fate, and eventually, because of this a common character". ${ }^{16}$ Mental patients were not recognized as individuals with mental health problems, rather they became mentally ill. Particular elements of an individual's life are selected through what Goffman refers to as 'social reworking'. ${ }^{17}$ He states that "...it might seem also to be true that almost anyone's life course could yield up enough denigrating factors to provide grounds for the record's justification of commitment". ${ }^{18}$ The goal here is to sift through an individual's past to

\footnotetext{
${ }^{13}$ For a detailed account of these changes see David Garland's "Culture of Control" and Meave McMahon's "The Persistent Prison".

${ }^{14}$ J. Ekstedt, and C, Griffiths, Corrections in Canada: Policy and Practice (Toronto: Butterworths publishing, 1988) at 52.

${ }^{15}$ D.J. MacNamara, "The Medical Model in Corrections: Requiescat in Pace" (1977) 14 Criminology. 439 at 440 .

${ }^{16}$ E. Goffman, Asylums (Chicago: Aldine Publishing Company, 1961) at 129.

${ }^{17}$ Ibid. at 159 .

${ }^{18}$ Ibid. at 129.
} 
select enough elements to justify their commitment as a mental patient. Treatment is then validated after having been established to be a mental patient, regardless of whether there is any truth to the claim that the individual is mentally ill. In addition, research reports highlighted the failure of asylums and argued that these institutional settings were understaffed, overcrowded and ineffective in curing mental illness. ${ }^{19}$

The 1960s and 1970s are a time in welfarism when the democratic rights of minority groups such as blacks, women, gays, prisoners, and mental health patients were increasingly affirmed and extended. ${ }^{20}$ As a result of important shifts in the balance of power between government and those governed, a number of competing interests in mental health, including that of academics, civil libertarians, physicians, drug companies and government, came together and collectively argued for the transfer of the mentally ill from institutional settings to a network of community established resources to assist the mentally ill in accessing treatment and alternative housing options. Although government and policy makers indicated that this shift was intended to provide a more compassionate form of treatment, the mentally ill were left wandering the streets and became increasingly in trouble with the law. It turned out that the institutions designed [in the welfare state] "to meet the population's need for housing, or healthcare, or social work, or income support had a tendency to discover more and more unmet need, so that the problems appeared to become larger [rather] than smaller". ${ }^{21}$

\section{Deinstitutionalization}

The movement of the mentally ill from community poorhouses to institutional settings in the mid to late 1800 s was initially intended to provide them with a more

\footnotetext{
${ }^{19} \mathrm{~S}$. Davis, Community Mental Health in Canada (Vancouver: UBC Press, 2006) at 104.

${ }^{20}$ Garland, supra note. 8 at 87.

${ }^{21}$ Ibid. at 93.
} 
humane form of treatment. For many, "the move to asylums represented a progressive shift, one that would provide safe settings for physical and spiritual care and...shield residents from the harm and peril that commonly befell people with mental illnesses in cities and towns". ${ }^{22}$ Canada's first asylum was built in New Brunswick and opened in $1836{ }^{23}$ The construction of other Canadian institutions closely followed this psychiatric hospital and were erected across Quebec, Ontario, Newfoundland, Prince Edward Island, Nova Scotia, British Columbia and Manitoba respectively.

American asylums, much like those in Canada, were often remote, overcrowded and housed mentally ill individuals for lengthy periods of time. These adverse characteristics prompted a series of studies, including that of Goffman, who conducted much of his research in the United States, to explore the effectiveness of the asylum in treating and responding to the needs of the mentally ill. Before long, it became evident in research findings that asylums were understaffed and unsuccessful in treating mental illness. ${ }^{24}$ Canadian Psychologist, Arboleda-Florez, notes that "the custodial, institutionbased model of care for those with mental illness contributed to their stigmatization by segregation" as well as "to the banishment of mental illness, and also from psychiatry from the general stream of medicine". ${ }^{25}$ Highlighting the establishment of new psychotropic drugs, lower economic costs and the failure of asylums, reformists argued for the transfer of the mentally ill from institutional settings to a network of community established resources to assist them in accessing alternative treatment options.

\footnotetext{
${ }^{22}$ Davis, supra note 18 at 104 .

${ }^{23}$ Ibid. at 104 .

24 Ibid. at 104.

${ }^{25} \underline{\text { Ibid. at }} 104$.
} 
Although the term "deinstitutionalization" was not coined until the 1970s, the downsizing of psychiatric hospitals in Canada began nearly a decade earlier. ${ }^{26}$ Bachrach describes this process as the replacement of long-term psychiatric hospitals with smaller, less isolated community-based service alternatives for the care of individuals with severe and persistent mental health problems. ${ }^{27}$ Beginning in the early 1960 s the shift towards community care emerged and institutions in Canada slowly began to downsize or close their doors. However, the promises made in the 1950 s and 1960 s of "community treatment' gave way to the gradual realization in the 1970 s that there were still many unresolved problems: mentally disordered persons were not connecting with care providers within their communities, and many mentally ill individuals were homeless or in jail. ${ }^{28}$ In order to gain a better understanding of why these problems materialized it is important to identify the different parties advocating for the move to community based care and the interest's driving their reform initiatives.

\section{Negative Research Findings and Changing Public Opinion}

During the 1950s the number of mentally ill individuals residing in both provincial and state hospitals reached their highest point, prompting a series of studies to explore the impacts of the mental health institution. Gray, Shone and Liddle reported that there were over 5,000 persons housed at the Essondale mental hospital in Vancouver, British Columbia, while in Saskatchewan 3,500 persons were kept in two large institutions near Saskatoon and Regina. ${ }^{29}$ A similar picture can be painted within the

\footnotetext{
${ }^{26}$ H.J. Steadman, D.W. MacCarty, \& J.P. Morrissey. The Mentally Ill in Jail (New York: Guilford; 1987) at 233.

${ }^{27}$ Bachrach, supra note 6 at 30.

${ }^{28}$ Davis, supra note 18 at 103 .

${ }^{29}$ J. Gray, M. Shone \& P. Liddle, Canadian Mental Health law and Policy. (Toronto: Butterworths; 2000) at 30 .
} 
United States as the number of mental patients escalated leading to overcrowded institutions. One of the first and most detailed studies to exploit the problems of the mental health institution was that of Goffman. Although Goffman conducted his work at the National Institute of Mental Health in Maryland, United States, his work is helpful in understanding the conditions under which the mental health patient existed here in Canada. During this time both the United States and Canada were facing similar pressures in responding to the expanding number of mentally ill individuals filling asylums. From 1954 to 1957 Goffman conducted a study in a mental health institute in an attempt to learn about the social world of the mental health patient. He found that the hospital could be best described as a 'total institution' characterized

as a place of residence and work where a large number of likesituated individuals, cut off from the wider society for an appreciable period of time, together lead an enclosed, formally administered round of life. ${ }^{30}$

Rather than providing differential treatment to each individual, Goffman found that the institution served to remake the mental patient by first stripping him of his identity and then molding him into a person who fit within the prevailing social arrangements of the institutional setting. ${ }^{31}$ Goffman classified individuals within the institution according to two separate spheres: 'The Inmate World' and 'The Staff World'. He found that there were a number of distinct features and behaviours associated with each group which guided their day to day operations within the institution.

Inmates typically live in the institution and have restricted contact with the world outside the walls; staff often operate on an eighthour day and are socially integrated into the outside world. Each grouping tends to conceive of the other in terms of narrow, hostile, and untrustworthy, while inmates often see staff as condescending,

\footnotetext{
${ }^{30}$ Goffman, supra note 15 at $\mathrm{x}$.

${ }^{31}$ Ibid. at 168.
} 
highhanded, and mean. Staff tends to feel superior and righteous; inmates tend, in some ways at least, to feel inferior, weak, blameworthy, and guilty. ${ }^{32}$

His findings revealed that the relationships which had developed between the patient and care-provider, was one that served to further segregate the mentally ill rather than being therapeutic in nature.

Goffman utilizes the term career, which he states can "refer to any social stand of any person's course throughout life" to describe, in detail, the steps involved in the "passage from person to patient". ${ }^{33}$ During the pre-patient phase the moral aspects of the career that the mental patient first experiences are those of "abandonment, disloyalty, and embitterment resulting from the patient's loss of relationships and rights. ${ }^{34}$ Goffman explains that these feelings of distrust stem from the fact that it is often an individual in a position of trust who takes the necessary action which leads to the mental patient's hospitalization. Once these relationships and individual rights have been severed the mental patient enters into the in-patient phase. "In the mental hospital, the setting and the house rules press home to the patient that he is, after all, a mental case...having failed in some overall way...being hardly capable of acting like a full-fledged person at all., ${ }^{, 35}$ The mental patient's old perception of himself as a person has been lost in his transition to patient and now his self constitutes the social controls of the institution. ${ }^{36}$

The moral career of the mental patient which Goffman describes is consistent with broader political rehabilitative welfarist approaches. The institution was used as a location where a person who was judged to be suffering from "sick behaviour" is

\footnotetext{
${ }^{32}$ Ibid. at 7.

${ }^{33}$ Ibid. at 127.

${ }^{34} \frac{\text { Ibid. at } 133 .}{1}$

35 Ibid. at 152.

${ }^{36}$ Ibid. at 153 .
} 
committed, and through the process of hospitalization is stripped of their identity and restored to acceptable social standards. "The self in this sense is no longer the property of the person to whom it is attributed, but dwells rather in the pattern of social control that is exerted in connection with the person by himself and those around him". ${ }^{37}$ This research illustrates that the type of care provided within the asylum during this period focused on breaking down individual identities, rather than treating a patient's individual mental illness. Planners in Canada failed to acknowledge that long-term "mental health patients vary significantly according to their diagnosis, symptoms, functional levels, treatment histories...and treatment needs". ${ }^{38}$ Studies, such as Goffman's, revealed that the move towards the asylum, which had contended to provide healing, served to further segregate the mental patient and perpetuate negative stigmas associated with being mentally ill. Research projects similar to Goffman's continued to reveal the negative impacts and anti-therapeutic conditions of the 'total institution'. These research results fueled civil libertarians and patient's rights groups to advocate for the rights of the mentally ill and implement a more humane form of treatment in the community.

During the same period of time that these research studies were published, a number of movies and novels were produced drawing the public's attention to the negative impacts of the asylum. The 1948 Oscar-nominated film The Snake Pit presented the viewer with an unsettling vision of how mentally ill individuals were historically confined in psychiatric institutions. ${ }^{39} \quad$ Furthermore, One flew Over the Cuckoo's Nest, originally Ken Kesey's 1962 acclaimed novel, and subsequently made into a film, is still

\footnotetext{
${ }^{37}$ Goffman. supra note 15 at 168.

${ }^{38}$ L. Bachrach, ed. "Mental Health Care in Canada" (1994) 61 New Directions for Mental Health Services. 1 at 5 .

${ }^{39}$ online: Rope of Silicon <http://www.ropeofsilicon.com/movies.php?id=1687>.
} 
used today to refer to a psychiatric hospital. This novel offers the reader insight into the lives of the mental health patient behind the doors of a psychiatric hospital during the 1950 s and 1960s. Kesey illustrates the way in which insanity is socially constructed by those in positions of authority to maintain insidious power over the hospital's patients. An example of this can be seen when Taber is sent for Electroshock treatments and possible brain work by head Nurse Ratched for asking which kind of medication he was being given. ${ }^{40}$ Here, Kesey portrays the inhumane operations of the institution when a patient is harshly punished for asking a legitimate question. These works are important for understanding shifts in thinking about the asylum and the treatment of mental patients.

Both research and media attention, which focused on the harmful impacts of the asylum, greatly influenced the movement of civil libertarians and patient's rights agendas. In fact, many researchers argue that it was the public's reaction to these films which brought the rights of the mentally ill to the forefront of legislation concerning their confinement in institutional settings. ${ }^{41}$ Beginning in the 1970 s the legislative detention criteria in the United States narrowed to focus on the key consideration of dangerousness. Generally, medical model proponents, who maintain that a psychiatric illness is genetic and can be diagnosed using a set of established criteria and then medically treated, opted for the principle of parens patriae. ${ }^{42}$ This principle essentially involves the obligation of the state to care for those of its citizens who are unable to care for themselves. ${ }^{43}$ Patient's rights advocacy groups argued that the idea of committing patients based on what was

\footnotetext{
${ }^{40}$ K. Kesey. One Flew Over the Cuckoo's Nest. (The Viking Press; New York, 1962). at 32.

${ }^{41}$ Davis, supra note 18 at 107.

${ }^{42}$ S. Olfman, Diagnosis, Drugs, and Bipolar Disorder in Children (Westport: Prager Publishers, 2006) at 128.

${ }^{43}$ Bachrach, supra note 37 at 42.
} 
thought best for their "own welfare" was no longer deemed acceptable. These legislative changes are significant because they reflect the broader political shifts in the move from the welfare state to contemporary neo-liberalism. "Voters who had previously been strong supporters of social democratic parties increasingly took the view that the welfare state no longer worked to their benefit". ${ }^{44}$ Political parties quickly reacted to the public's declining support of welfarist approaches and advocated to "get back to basics and reimpose "individual responsibility", 45

Although these legislative changes occurred during the deinstitutionalization movement within American jurisdictions, it was not until 1979 when the first Canadian Province, Ontario, implemented these standards into its Mental Health Act. ${ }^{46}$ During this time there was also a shift away from the continuum model of mental health toward an increased emphasis on a discrete or dichotomous model of mental illness where one is either sick or well. ${ }^{47}$ "In this view, people who are mentally ill are placed into specific disease categories by the identification of specific symptoms". ${ }^{48}$ Policy frameworks shifted towards individualized care and the leading principle guiding the field of mental health became no treatment without diagnosis. ${ }^{49}$ These shifts in understanding mental illness have specific consequences for the kinds of supports which need to be available in the community. It is important to acknowledge that mental illness affects individuals in varying degrees at different periods of time throughout their lives. Although an individual may be considered independent and responsible, they may still require a

\footnotetext{
${ }^{44}$ Garland, supra note 8 at 96.

45 Ibid. at 99.

${ }^{46}$ Davis, supra note 18 at 273.

${ }^{47}$ A. Horwitz, \& Scheid, T. ed. A Handbook for the Study of Mental Health. Cambridge University Press: Cambridge. at 2.

48 Ibid at 2.

${ }^{49}$ Garland, supra note 8 at 36.
} 
significant amount of support. We will see throughout this paper that these shifting perspectives continue to impact approaches to dealing with mentally ill individuals.

\section{Development of Psychotropic Drugs}

In addition to the strong research reporting the inadequacy of mental health facilities, this shift was also motivated by the development of new psychotropic drugs emerging in the 1950s. These newly established pharmaceutical companies would later become one of the leading influential players in the mental health field. The success of these companies was dependant on the support of physicians and psychiatrists working with the mentally ill. Drug companies argued that the discovery of chlorpromazine and lithium, and the development of community psychosocial approaches to treatment would enable mentally ill individuals to successfully manage the symptoms of their illnesses while living in the community. ${ }^{50}$ In addition, advocates also presumed that the new medication would be taken voluntarily by patients in the community. As a result, proponents of the deinstitutionalization movement encouraged mental health practitioners to release patients into the community to reside with family, in boarding homes, and even in their own individual apartments. Perhaps driven by their economic interests, drug companies supported the shift towards community care and encouraged the liberation of the mentally ill.

\section{Government}

Although reform initiatives outlined by policy makers within the Government appeared well intended, it was their modes of implementation which hindered the effectiveness of deinstitutionalization. Rothman contends that

\footnotetext{
${ }^{50}$ Lamb, supra note 5 at 3 .
} 
an effort [was] made to conjure up a mythical "Golden Age": an innocent, robust society uncorrupted by bureaucracy, where neighbour helps neighbour and families willingly minister to the needs of their own troublesome members, while a benevolent and indulgent squirarchy looks on, always ready to lend a helping hand. ${ }^{51}$

The Government utilized positive rhetoric, such as "community living" and "deinstitutionalization" to romanticize the movement of mentally ill individuals into the community. Family involvement was highlighted as one of the most important components in ensuring that the needs of the mentally ill were met during this transition. However, the family was never consulted by physicians or psychiatrists with regard to their role in facilitating the movement to community treatment. In fact, history suggests that the relationship between physicians and family was one that was characterized by ambivalence and often mistrust. ${ }^{52}$

Operating concurrently during the period of deinstitutionalization from the $1950 \mathrm{~s}$ through to the 1970s was the development of psychodynamic theories which blamed families for the presence of mental disorders, such as schizophrenia. These theories turned to early childhood experiences for mental health explanations, which are now attributed to biological based characteristics. ${ }^{53}$ Psychiatrists often accounted for the etiology of schizophrenia by proposing the concept of the cold, rejecting "schizophrenogenic mother", the "double-bind" hypothesis (an investigation of the contradictory messages from the parent), or the role of the marital "schism and skew" in

\footnotetext{
${ }^{51}$ Rothman, supra note 4 at 8.

${ }^{52}$ Davis, supra note 18 at 85 .

53 Ibid. at 85.

${ }^{54} \mathrm{My}$ discussion of these theories which attribute blame to family dynamics or relationships as a cause of their child's mental illness is to illustrate the range of public perception towards mental illness during this time period. I recognize that several scientific studies have been conducted and found that mental illness is rooted in biology, not caused by disturbances in family relationships.
} 
the families of persons with schizophrenia. ${ }^{55}$ Each of these theories attributed mental illness to poor family dynamics. It is clear that while drafting the policies surrounding the deinstitutionalization movement the government failed to consider the impacts of these influences on psychiatry. On the one hand the field of psychiatry was purporting that the family was responsible for their family member's illness, while on the other the government was highlighting the important therapeutic role of the family in facilitating the success of the movement to community care.

Phrases like "community-based services" and "community treatment" were utilized to promote the movement. Beginning in the early 1960 s the decrease in inpatient populations emerged and institutions in Canada slowly began to downsize or close their doors. Health and Welfare Canada's overall estimate regarding the decrease in the number of in-patient beds in psychiatric hospitals was from 4 per 1000 people to less than 1 per 1000 population in $1970 .^{56}$ However, the most significant reduction in bed capacity in psychiatric hospitals (from 53,801 to 20,301 ), illustrated in Table 1.1 below, occurred in Canada between 1975 and 1980 to $1981 .^{57}$ This chart clearly demonstrates the variations in bed closures across provinces.

\footnotetext{
${ }^{55}$ Ibid. at 86.

${ }^{56}$ E. Latimer, "Community Based Care for People with Severe Mental Illness in Canada" 28 International Journal of Law and Psychiatry. 561 at 565.

${ }^{57}$ Statistics Canada Mental Health Statistics (1983) Vol. III Institutional Facilities Services and

Finances1980-1981.
} 
Table 1. Rated Bed Capacity of Operating Institutions by Province Per 1,000 Population, 1965 to 1980/1981

\begin{tabular}{|c|c|c|c|c|c|c|c|c|c|c|c|}
\hline Year & Canada & Nfld & P.E.I. & N.S. & N.B. & Que. & Ont. & Man. & Sask. & Alta. & B.C. \\
\hline 1965 & 69128 & 844 & 391 & 3043 & 2102 & 19157 & 23968 & 3686 & 3586 & 5980 & 6371 \\
\hline 1970 & 64758 & 895 & 391 & 1897 & 1877 & 20771 & 21342 & 2933 & 2861 & 5023 & 6768 \\
\hline 1975 & 53801 & 525 & 295 & 1792 & 1318 & 17477 & 17546 & 2670 & 1895 & 4681 & 5602 \\
\hline $1980-81$ & 20301 & 357 & 256 & 821 & 1074 & 3008 & 7935 & 1157 & 702 & 1619 & 3372 \\
\hline 65-81 Decrease & 48827 & 487 & 135 & 2222 & 1028 & 16149 & 16033 & 2529 & 2884 & 4361 & 2999 \\
\hline$\%$ Decrease & $70.6 \%$ & $57 \%$ & $34.5 \%$ & $73 \%$ & $48.9 \%$ & $84.3 \%$ & $66.9 \%$ & $68.6 \%$ & $80.4 \%$ & $72.9 \%$ & $47 \%$ \\
\hline 1965 Rate/ Pop. & 3.5 & 1.7 & 3.6 & 4 & 3.4 & 3.4 & 3.6 & 3.8 & 3.8 & 4.1 & 3.6 \\
\hline $\begin{array}{l}\text { 1980-1981 Rate/ } \\
\text { Pop. }\end{array}$ & 0.8 & 0.6 & 2 & 1 & 1.5 & 0.5 & 0.9 & 1.1 & 0.7 & 0.7 & 1.3 \\
\hline$\%$ Change & -2.7 & -1.1 & -1.6 & -3 & -1.9 & -2.9 & -2.7 & -2.7 & -3.1 & -3.4 & -2.3 \\
\hline
\end{tabular}

Statistics Canada Mental Health Statistics (1983): Vol. III Institutional facilities services and finances 1980-1981:15. 
Deinstitutionalized patients were not warmly welcomed by the general public and experienced difficulty accessing sparse community mental health and welfare agencies to assume responsibility for their care. ${ }^{59}$ In 1979 , years after the elimination of in-patient psychiatric beds, the Ontario Council on Health criticized the Ministry for not making mental health a priority and for providing "totally inadequate" aftercare services. ${ }^{60}$ It was not until the late 1980s that explicit policies were implemented in Canada in support of deinstitutionalization. ${ }^{61}$ Furthermore, only in the 1990 's were intensive case management programs developed in Canada for individuals suffering from severe mental illness in the community. ${ }^{62}$ Some studies suggest that the lack of a coherent policy framework and, in some cases, lack of government support for community development initiatives have significantly impeded support of individuals in communities. ${ }^{63}$ A further explanation for the reluctance of community support is evidenced in an American study which suggests that since the adoption of the dangerousness criterion, discussed previously, for civil commitment, negative perceptions of mental illness have increased significantly. ${ }^{64}$

After spending long periods of time living in a hospital setting and abiding by rigid time schedules, mentally ill individuals were unaware of how to take responsibility for themselves. Over time, family connections had often deteriorated and governments had not adequately funded community resources to support the individualized needs of

\footnotetext{
${ }^{59}$ Steadman, supra note 24 at 234.

${ }^{60}$ Ontario Council on Health "Agenda for Action: Report of the Committee on Mental Health Services in Ontario" (Toronto: Ontario Ministry of Health, 1979).

${ }^{61}$ For a detailed outline of these policies please see Ontario Ministry of Community and Social Services. Challenges and Opportunities: Community Living for People with Developmental Handicaps. (Toronto: Queen's Printer for Ontario, 1987). and Canadian Association of Independent Living Centres. Independent Living: An agenda for the '90s. (Ottawa: Canadian Association of Independent Living Centres, 1993).

${ }^{62}$ Latimer, supra note. 54 at 568.

${ }^{63}$ The Roeher Institute. Research Issues in Evaluating Deinstitutionalization. November 6, 1995 at 27.

${ }^{64}$ J. Phelan and B. Link. "The Growing belief that people with mental illnesses are violent: the role of the dangerousness criterion for civil commitment" 33 Journal of Social Psychiatry. S7 at S11.
} 
the mentally ill. Hoge reported that upon entering the community setting, mentally ill individuals encountered a number of difficulties including:

difficulty finding and accessing services, denial of services to patients who need them, lack of accountability and follow-up for individual patients, absence of co-ordination among providers, lack of community in treatment planning, reimbursement schemes containing disincentives for community based and rehabilitative treatments, few if any incentives for efficiency or cost saving, and inadequate systems for monitoring the necessity, appropriateness, and effectiveness of care. ${ }^{65}$

Before long, it became clear that governments had not considered how they were going to adequately address the needs of deinstitutionalized mentally ill individuals.

\section{Funding}

Changes in policy within the Canadian mental healthcare system over time have largely focused on containing costs and as a result, have created a number of systemic problems. The creation of the Hospital Insurance and Diagnostic Services Act in 1957 drastically cut mental health funding within the healthcare system by excluding the operating costs of provincial mental hospitals from its hospitalization benefits. ${ }^{66}$ Researchers postulated that the cut in funding would encourage the use of general hospital's psychiatric units and the growth of these hospitals more broadly. As expected, hospitals continued to grow from 23 in 1957 to 169 in $1977 .{ }^{67}$ In effect this created what was recognized as a two-tier system. The provincial hospitals, with inadequate staffing and care, continued to treat the severely and chronically mentally ill, while the general hospitals were only equipped to treat patients for short-term situational problems. ${ }^{68}$

\footnotetext{
${ }^{65}$ M.A. Hoge, "Defining Managed Care in Public Sector Psychiatry" (1994) 45, Hospital and Community Psychiatry, 1085 at 1089.

${ }_{66}^{6}$ Bachrach, supra note 37 at 19.

${ }^{67}$ Ibid. at 19.

${ }^{68} \underline{\text { Ibid. }}$ at 19.
} 
Despite the poor working conditions for understaffed and underpaid nurses and doctors the provincial psychiatric institutions remained open.

It was only after the Canada Assistance Plan was introduced in 1966 and a financial gain was realized that the provincial hospitals began to close their doors. By moving the chronically mentally ill from provincial hospitals into boarding homes in the community the province could now claim up to 50 percent of the costs of these patients. ${ }^{69}$ Skull notes that this was a broader trend in North America and argues that governments saw this as an opportunity to offload costs by closing hospital wards and discharging patients into the community. ${ }^{70}$ As a result, from 1962 to 1977 the populations of provincial psychiatric hospitals fell by 78 percent and many closed down their doors. ${ }^{71}$ These financial changes meant huge savings for government. Unfortunately, the savings thus realized were not reinvested in the system by developing community support initiatives.

\section{Implications for Poorly Implementing Deinstitutionalization}

\section{The Homeless Mentally Ill}

Not only were the mentally ill unable to access the community treatment and service providers they required, they were also unable to find suitable housing options. Reformists of the deinstitutionalization movement had purported that the move from institutional settings to smaller community based residences would be a smooth and easy transition for mentally ill individuals. Instead, many mentally ill individuals now found themselves homeless, without family support, and living in emergency shelters. As a

\footnotetext{
${ }^{69}$ Bachrach, supra note 37 at 19.

${ }^{70}$ A. Scull, Decarceration: Community Treatment and the Deviant - A Radical Review. (New Jersey: Englewood Cliffs; 1977) at 57.

${ }^{71}$ Bachrach, supra note 37 at 19.
} 
result, the homeless mentally ill experience a number of adversities while residing in shelters and living on the street. Davis found that

Homeless persons with mental disorders experienced more hardships on the streets, took greater public health risks, more often abused substances, were more often victimized, suffered greater negative economic and interpersonal life events, experienced greater dissatisfaction, and suffered more stress. ${ }^{72}$

Many of these hardships exacerbate the symptoms of their mental illness. Research findings point out that "adequate and appropriate housing is often the essential ingredient needed to help people with mental illness move forward toward recovery". ${ }^{73}$ The structured living environment which had once been provided to them was now replaced with a disorganized and harmful lifestyle.

Some studies have defined homelessness narrowly, referring to the absolute homeless- persons "living rough" or in emergency shelters - or in relative terms, referring to people "who pay too much of their income for rent, or are residing in inadequate housing, or lack security tenure" 74 The definition of adequate housing provided by the United Nations includes five standards: (1) protection from the elements, (2) access to safe water and sanitation, (3) secure tenure and personal safety, (4) access to employment, education, and health care, and (5) affordability. ${ }^{75}$ Because definitions and descriptions of homelessness vary across studies it is difficult to provide a standard estimate on the rate of homeless mentally ill individuals.

\footnotetext{
${ }^{72}$ Davis. supra note 18 at 159.

${ }^{73}$ Ibid. at 156.

${ }^{74}$ M. Eberle, "The Relationship between Homelessness and the Health, Social Services and Criminal Justice System: A Review of the Literature" (2001) 1 Homelessness: Causes and Effects. 1 at 22.

${ }_{75}$ T. Bryant, "The Current State of Housing in Canada as a Social Determinant of Health" (2003) Policy Options. 52 at 54.
} 
Results from empirical studies suggest that since the movement of deinstitutionalization there have been increases in numbers of mentally ill individuals amongst the homeless population. American studies reveal that "about 35 percent of the homeless population have a "severe mental illness", referring mainly to persons with psychotic disorders, bipolar disorder, and major depression...and increases to 75 percent if one includes alcohol and drug addictions as mental disorders". ${ }^{76}$ After conducting a review of the literature Davis found that studies which have been conducted in Canada report similar findings. Some of these research reports include the 1993 study on emergency shelters in Vancouver, which found that one in five individuals met the criteria for schizophrenia, bipolar disorder, or major depression listed in the American Psychiatric Association's Diagnostic and Statistical Manual (DSM). ${ }^{77}$ In 1999, Golden and colleagues conducted a survey in Toronto and found that 30 percent of the city's homeless population suffered from a mental disorder. ${ }^{78}$ These findings reveal that there are a significant number of mentally ill individuals who have not been able to access the necessary community supports and alternative housing options. Although the policy makers purported that a network of community resources would be available these findings illustrate that the Government failed to implement the necessary funding. Increased Encounters with the Criminal Justice System

Without the availability of adequate case management and appropriate living accommodations, the population of homeless mentally ill individuals continues to expand. Chances of police encounters with individuals on the streets have become a

\footnotetext{
${ }^{76}$ Davis, supra note 18 at 158.

${ }^{77} \mathrm{~S}$. Acorn. "Mental and physical health of homeless persons who use emergency shelters in Vancouver" (1993) 44 Hospital and Community Psychiatry. 854 at 856.

${ }_{78}$ A. Golden, Report of the Mayor's Homelessness Action Task Force: Taking Responsibility for the Homeless: An Action Plan for Toronto (Toronto: City of Toronto, 1999).
} 
more likely scenario today -often resulting in an arrest. As Shah found, "mentally disordered offenders have a significantly greater chance of being arrested, as compared to non-mentally disordered offenders". ${ }^{79}$ Since the deinstitutionalization movement in the 1970 s research reports indicate an increase in the number of homeless mentally ill individuals within jail populations. In fact, there have been a number of studies showing that the prevalence of serious, persistent mental disorders in remand/pre-trial centres and prison populations far exceeds that seen in the general population. ${ }^{80}$ Remand and pretrial centres are not appropriately equipped to recognize or respond to the specialized needs of mentally ill offenders.

A large number of studies were reviewed to identify the prevalence of mental disorder among jail detainees. Researchers "found rates ranging from $5 \%$ to $12 \%$ for severe mental disorder and from $16 \%$ to $67 \%$ for any mental illness. There is also evidence that a large percentage of these individuals may also have been homeless at the time of the arrest." ${ }^{, 81}$ Literature from both the United States and Canada illustrates that homelessness coupled with mental illness is a strong predictor of involvement with the criminal justice system. ${ }^{82}$ Several surveys, including two Canadian studies, have shown that among homeless people, those who report psychiatric illness or previous

\footnotetext{
${ }^{79}$ S. A. Shah \& B. D. Sales, Eds. "The criminalization hypothesis: Myth, misnomer, or management strategy" Law and Mental Health: major developments and Research Needs (United States; Rockville, 2001). 149 at 180.

${ }^{80}$ Davis, supra note 18 at 173 . Remand facilities are used to house inmates for short periods of time when the accused must make a number of court appearances before a trial date is set. The General population that Davis is referring to houses accused individuals who have been sentenced or are waiting for trial.

${ }^{81}$ P.A. Zapf, R. Roesch, \& S.D. Hart. "An examination of the relationship of homelessness to mental disorder, criminal behavior, and health care in a pretrial jail population" (1996) 41Canadian Journal of Psychiatry, 435 at 435.

82 R. Vitelli, "The homeless inmate in a maximum-security prison setting" (1993) 35 Canadian Journal of Criminology, 323 at 440.
} 
hospitalization are most likely to have a history of arrest or incarceration. ${ }^{83}$ These studies argue that the criminal justice system has replaced the mental health system as a primary provider of mental health care to homeless people.

Like homelessness, the incarceration of the mentally disordered has been linked to the larger numbers of these persons now present in the community because of psychiatric hospital downsizing and to the fact that community treatment and support services are ineffective and/or unresponsive. $^{84}$

I am not arguing that people with mental illness are inherently criminal; rather, that by virtue of their homelessness they are more likely to encounter police. In many circumstances these encounters might not have occurred if those mentally ill in question had been receiving adequate and appropriate mental health services.

Steadman and Morrissey describe this transition of patient flow from one institutional setting to another as "Transinstitutionalization". 85 "In this era of deinstitutionalization, the criminal justice system has taken the place of the psychiatric hospitals in becoming the institution that cannot say no." ${ }^{~ 86}$ Individuals in need of mental health services are ineffectively being dealt with by the criminal justice system.

When examining the population of mentally ill individuals in remand/pre-trial centres it is important to consider the relationship between mental illness and substance abuse. The term dual diagnosis has been defined by the Canadian Mental Health Association to refer to "an individual who has both a major psychiatric disorder such as

\footnotetext{
${ }^{83}$ Ibid at 445.

${ }^{84}$ S. Davis, "Assessing the criminalization of the Mentally Ill in Canada." (1992) 8 Canadian Journal of Psychiatry. 532 at 535.

${ }^{85}$ Steadman, supra note 25 at 228.

${ }^{86}$ Lamb, supra note 5 at 11.
} 
schizophrenia, and a substance use or alcohol problem" ${ }^{87}$ Minkoff reviewed a number of Canadian studies and found that rates of substance dependence among persons with serious, persistent mental disorders range from 15 to 40 percent and rates of substance abuse ranging from 32 to 85 percent. $^{88}$ One of the explanations provided for the high prevalence of concurrently diagnosed offenders is the greater availability of illegal substances within city centres where many emergency shelters are located. Also, some individuals turn to drugs or alcohol to numb the symptoms of their mental illness, however, this often only exacerbates the problem. Unfortunately, for many homeless mentally ill, the combination of living in city centres where there is a strong police presence and availability drugs and alcohol they are more likely to have encounters with the law. As the rates of mentally ill individuals who abuse substances increases, community resources must be implemented which are designed to respond to concurrent disordered offenders.

\section{$\underline{\text { Conclusion }}$}

A review of the mental health system's response to individuals suffering from mental health problems reveals a cyclical pattern of ineffective treatment and care for these individuals. The movement of deinstitutionalization was clearly impacted by a number of social, economic and political factors. Rather than receiving liberation and greater individualized care within the community, the mentally ill have experienced a transition from asylums, to emergency shelters, to the criminal justice system. The agendas of reformists advocating for the liberation of the mentally ill were driven by

\footnotetext{
87 "Mental Illness Glossary" online: Canadian Mental Health Association $<$ http://www.cmha.ca/bins/content_page.asp?cid=3-424\&lang=1>.

${ }^{88} \mathrm{~K}$. Minkoff, "Program Components of a comprehensive system for seriously mentally ill patients with substance abuse disorders" (2001) 91 New Directions for Mental Health Services. 17 at 25.
} 
personal and sometimes conflicting interests. Furthermore, the use of positive rhetoric like "community treatment" and "therapeutic care" by governments was intended to appease civil libertarians and patient's rights groups rather than to provide adequate care. Mentally ill individuals now increasingly find themselves not only battling their illness but are faced with increased involvement with both the criminal justice system and dealing with substance abuse problems. Although I do not concede that these reforms were ill-intended, governments too hastily moved individuals into the community before implementing the adequate support services required to respond to their needs. 


\section{Chapter 2: Responsibilizing the Mentally Ill Offender}

\section{Introduction}

Although the mentally ill offender still exists throughout shifting discourses and practices, it is the way that the criminal justice system deals with this individual which changes. In the move from the welfare state in the post WWII period to contemporary neoliberalism the illness becomes individualized but the offender remains problematic. It is apparent in this shift that the mental patient of the 1900 s is very different than the individual suffering from mental health problems of the 1970s. By illustrating the different understandings of the mentally ill offender we can see a broader reflection of the changing social and political perspectives.

\section{Changes in Punishment}

Although the goal of rehabilitating the individual offender has existed for more than 200 years, the techniques employed to achieve this reformation have changed significantly. Throughout the history of crime and punishment in Canada "the practice of changing people has included physical torture, carceral regimes relying heavily on religion, psychological interventions like psychoanalysis, group therapy and individual counseling, physical interventions like lobotomies and pharmacological administrations including a range of psychoactive substances". ${ }^{89}$ The employment of one of these particular types of punishment regimes is, and has been largely dependant on the broader changing political, social and economic forces. ${ }^{90}$

\footnotetext{
${ }^{89}$ D. Moore, 2007.

${ }^{90}$ D. Garland, "The limits of the sovereign state: strategies of crime control in contemporary society" (1996) 36 British Journal of Criminology 445 at 446.
} 
Many theorists argue that from the 1970's onward the support of the rehabilitative ideal has dwindled. ${ }^{91}$ In its demise several academics have attempted to characterize the contemporary penal framework which has taken its place. Simon and Feeley argue that we are now experiencing the "new penology" which is not so much concerned with responsibility, fault, moral sensibility, diagnosis, or intervention and treatments of the individual offender, rather, this new method of understanding crime "is concerned with techniques to identify, classify and manage groupings sorted by dangerousness".92 Feeley and Simon contend that the "new penology" is characterized by shifts in three distinct areas: a new focus on probability and risk, the objectives of control, and targeting groups of offenders rather than individuals. ${ }^{93}$ On the contrary, Garland argues that the correctional and welfarist approaches have not become entirely extinct, but rather a more cautious description of what has occurred may be that their rationales have faded over time. $^{94}$ He contends that rehabilitative programs continue to operate; however, they no longer constitute the overarching ideologies of our penal system. ${ }^{95}$ Garland also stresses that when looking at the penal system one must consider changing cultural assumptions and political interests which shape the practices of punishment. ${ }^{96}$ O'Malley's account of penal modernism captures a bewildering array of "contradictory and volatile" developments operating concurrently with one another. Instead of having one grand narrative of punishing, what we are experiencing is a meshing of neoliberal ${ }^{97}$ and

\footnotetext{
${ }^{91}$ M. Feeley, and J. Simon, "The New Penology: Notes on the Emerging Strategy of Corrections and its Implications" (1992) 30 Criminology 449. and Garland, Supra note at 1.

92 Ibid. at 452.

93 Ibid. at 450.

${ }^{94}$ Garland, supra note 8 at 8 .

${ }^{95}$ Ibid. at 8 .

96 Ibid. at 9.

97 I use the term neo-liberalism here to refer to the broader socio-economic trends that characterize our present. Borrowing from O'Malley (1999) neo-liberalism is understood as a style of governing that
} 
neoconservative ${ }^{98}$ concepts of punishing, creating a penal scheme that is both efficient and punitive, an approach O'Malley dubs the "new right". 99

At the other end of the spectrum there is a body of American literature that offers a much different theory of contemporary justice. Nolan convincingly argues that we have moved towards a culture which is defined by therapeutic practices and policies which guide our legal and governing discourses. ${ }^{100}$ His work examines the rise of drug treatment courts in America and the justice system's increasing commitment to therapeutic sensibilities. $^{101}$ Similarly, we have witnessed the development of mental health courts here in Canada which are also heavily influenced by ideas of therapeutic justice. $^{102}$ Many of these courts, which have been established internationally, are based on the assumption that treatment will enable the mentally ill offender to break the cycle of multiple arrests, better known as the "revolving door".

It appears that despite the disagreement in characterizing the current model of penal practice, a strong argument can be made for the existence of rehabilitative regimes. While it is evident that the medical model of rehabilitation was abandoned as an accepted purpose of imprisonment, "that does not mean that rehabilitation either as a concept or a practice that may benefit individual offenders has been removed from the correctional

privileges macroeconomics and fiscal responsibility and by diverting potentially profitable activities into non-profit state agencies and reaffirming individual responsibility. With regard to criminal justice settings, neo-liberalism often includes tailoring policies around notions of efficiency, responsibilizing the individual offender and initiatives like privatizing penal and policing services (Ericson \& Haggerty, 1997).

${ }^{98}$ The term neo-conservative is employed here to indicate approaches to governing that draw heavily on morality and often religion to guide practice. In criminal justice terms, neo-conservativism often indicates regimes with mandatory minimum sentences, extended prison terms and capital punishment.

99 Moore, supra note 87 at 40.

${ }^{100}$ J. Nolan, The Therapeutic state; justifying government at century's end (New York: York University, 1998).

${ }^{101}$ J. Nolan, Reinventing justice: The American drug court movement (Princeton: Princeton University Press, 2001) at 254.

${ }^{102}$ D. James, "Court Diversion in Perspective" (2006) 40 Australian and New Zealand Journal of Psychiatry 529 at 529. 
enterprise". ${ }^{103}$ Cullen argues that it was the work of twelve individuals who remained committed to rehabilitative correctional practices "which enabled them to persist alongside the more punitive tendencies evident in many regimes throughout the late 1980 s". ${ }^{104}$ Cullen states that

three decades ago it was widely believed by criminologists and policymakers that "nothing works" to reform offenders and that "rehabilitation is dead" as a guiding correctional philosophy. By contrast, today there is a vibrant movement to reaffirm rehabilitation and to implement programs based on the principles of effective intervention. ${ }^{105}$

It may not be that there is a clear demarcation from a particular set of correctional practices as some penal theories postulate, but rather as O’Malley suggests each persists alongside one another. "Thus, while various movements share the assumption that those in conflict with the law can change (or be changed), each movement has a different set of [guiding] policies". ${ }^{106}$

Although the mentally ill offender still exists within the criminal justice system she is notably different than her insane, confined counterpart from the 1950s. Today, persons with mental illness are responsible, and can change their criminal behaviour by accessing treatment and the support of community mental health services. These changes in recognizing the contemporary mentally ill offender can be seen in the variations of policy and legal practice governing their involvement at the interface of the criminal justice and mental health systems.

\footnotetext{
${ }^{103}$ Eskedt, supra note 13 at 30.

${ }^{104}$ D. Moore, supra note 87 at 49.

105 F. Cullen, "The Twelve People who Saved Rehabilitation: How the Science of Criminology Made a Difference" (2005) 43 Journal of Criminology Volume 1 at 1.

${ }^{106}$ Moore, supra note 87 at 50.
} 


\section{Charting the Rise of Contemporary Neoliberalism}

It is apparent within the mental health and criminal justice systems that there are a number of projects that are influenced by different political and social frameworks, but are operating concurrently on mentally ill offenders. Until the early 1990s the Criminal Code of Canada had remained stagnant to social and political changes, however, the introduction of Bill C-30 following the decision of $R$ v. Swain dramatically changed the ways with which mentally ill offenders were dealt by the criminal justice system in Canada. Despite assertions that we have entered into a neo-liberal state, I argue welfarist approaches are omnipresent at the interface of the mental health and criminal justice system. Since the 1980s, there have been a number of reports published in the Province of Ontario that direct the Government to invest in community mental health services following the closure of psychiatric hospitals - a clear example of neo-liberal strategy working in tandem with welfarist thinking. The fluctuation between contradictory welfarist and contemporary neo-liberalist approaches operating in conjunction with one another create a number of specific problems for the care and treatment of mentally ill offenders.

While there is still a push to manage mentally ill individuals through the use of medication, political parties that have formed governments in Ontario since 1983 have agreed that it is vital to provide adequate mental health services in the community. Since this time 20 reports have been published in the province highlighting the need for the Ontario government to implement a comprehensive community mental health system. ${ }^{107}$ The Graham Report, published in 1988, stated that "the goal of the Ministry of Health

\footnotetext{
${ }^{107}$ R. Graham. "Building Community Support for People: A Plan for Mental Health in Ontario" (1988) Ontario.
} 
and Long Term Care should be to allocate 60 percent of the mental health funding envelope to community services and 40 percent for hospital care by $2003{ }^{\prime \prime} .{ }^{108}$ In 1993 the recommendations made in the Graham Report were endorsed in "Putting People First: The Reform of Mental Health Services in Ontario" and the province embarked on a ten year plan for mental health reform. ${ }^{109}$ When the report of Dan Newman (MPP), former Parliamentary Assistant to the Minister of Health and Long Term Care, "2000 and Beyond: Strengthening Ontario's Mental Health System" was published in 1998 he acknowledged that although the former Progressive Conservative Government had endorsed the ten year plan, they failed to allocate the necessary funding to successfully implement it. ${ }^{110}$ Although each of these reports argues that real investment is required in order to ensure that individuals suffering from mental illness can receive a continuum of care and service in their communities, many community organizations, such as, the Canadian Mental Health Association (CMHA), have argued that real investment has not taken place. ${ }^{111}$ It is clear within these reports that we can still see the rhetoric of the welfare state. Political parties continue to place a great deal of pressure on the government to assume responsibility for the mentally ill and provide the necessary funding for support services. However, rather than assuming the responsibility of the welfare state, recent reports and policy documents emphasize neoliberal imperatives. Now, governments are mandating policies which divest their responsibility onto

\footnotetext{
108 Ibid. at 80.

109 "Putting People First: The Reform of Mental Health Services in Ontario" (The Ministry of Health; 1993) online: Canadian Mental Health Association $<$ http://www.ontario.cmha.ca/docs/system/puttingpeoplefirst.pdf>.

${ }^{110}$ D. Newman, "2000 and Beyond: Strengthening Ontario's Mental Health System" (1998) online: Ministry of Health and Long Term Care $<$ http://www.health.gov.on.ca/english/public/pub/mental/mentalreform.html >.

111 "Chronology of Reports, Recommendations and Plans for Mental Health Reform" online: Canadian Mental Health Association $<$ http://www.ontario.cmha.ca/content/mental health_system/reform_chronology.asp $>$.
} 
community organizations and services to care for marginalized populations like the mentally ill.

\section{Identifying the Mentally Disordered Offender}

As governments supported the move to a "more orderly, more disciplined, more tightly controlled society" rates of incarceration began to rise. ${ }^{112}$ Among the groups to be impacted by these new political ideologies were the mentally ill. Until the early 1990s the Criminal Code of Canada had not reflected social and political changes, however, the introduction of Bill C-30 following the decision of $R v$. Swain dramatically changed the way in which mentally ill offenders were dealt with by the forensic system in Canada. ${ }^{113}$ The provisions outlined in Bill C-30 mandated a number of sweeping reforms, requiring various procedural protections to individuals ordered for an assessment of their fitness or criminal responsibility, and those who were acquitted due to mental illness. These reforms are a reflection of a neoliberal commitment to imposing individual responsibility.

Mr. Swain had been found "not guilty by reason of insanity" on a charge of aggravated assault on his wife and assault on his children. ${ }^{114}$ After his arrest Mr. Swain was treated for a psychiatric illness and was released into the community for a year and a half until the date of his trial. At trial the Crown successfully raised the insanity defence and Mr. Swain was kept under the pleasure of the Lieutenant Governor for nearly three months before he was granted an absolute discharge. ${ }^{115} \mathrm{Mr}$. Swain appealed the decision to the Ontario Court of Appeal on the basis that "there was no judicial discretion as to

\footnotetext{
112 D. Garland. supra note. 8 at 99.

${ }^{113}$ Forensic psychiatry is a division of psychiatry which provides specialized interdisciplinary services to individuals who are suffering from a severe mental illness and have come into conflict with the criminal justice system.

${ }_{114}$ R v. Swain 63 C.C.C. (3d) 193 (S.C.C.) 1991.

115 Ibid. at para. 8.
} 
sentencing, there was no hearing into the accused's mental condition at the time of trial as compared to how he was at the time of the offence, and the only provision following a successful finding of insanity was indeterminate detention". ${ }^{116}$ Although Mr. Swain's appeal was dismissed in the Court of Appeal, he was granted recourse in the Supreme Court of Canada where he was successful.

This decision is significant for two reasons. First, the legislative changes made to the Criminal Code regarding the insanity defence from "not guilty by reason of insanity" to "not criminally responsible on account of mental disorder" reflect the government's increased emphasis on individual responsibility in contemporary neo-liberalism. Furthermore, as a result of changes made regarding forensic psychiatric assessments there has been a documented increase in the number of mentally ill individuals involved with the criminal justice system. As a result of these changes and the continued failure of the neoliberal state to develop a sufficient supply of community mental health services despite the rhetoric of mental health reform since deinstitutionalization, undue stress has been placed on the mental health and criminal justice systems to effectively deal with these types of offenders.

In response to Mr. Swain's appeal in 1991 the Supreme Court of Canada struck down what was then Section 614(2) of the Criminal Code which provided for the automatic detention in custody of any defendant acquitted by reason of insanity to be kept in 'strict custody' until the pleasure of the lieutenant governor of the province was decided. At this time there were no procedural safeguards in place for mentally ill individuals and as a result they could be held in custody for indefinite periods of time.

\footnotetext{
${ }^{116}$ J. Arboleda-Florez, "The Effects of Changes in the Law Concerning Mentally Disordered Offenders: The Alberta Experience with Bill C-30" 40 Canadian Journal of Psychiatry June 1995225 at 226.
} 
On behalf of the court, Chief Justice Lamer ruled that Section 614(2) infringed on individual rights protected in Section 7 and 9 of the Canadian Charter of Rights and Freedoms.

Section 7 safeguards "the right to life, liberty and security of the person and the right not to be deprived thereof except in accordance with the principles of fundamental justice," while section 9 enshrines "the right not to be arbitrarily detained or imprisoned."117 Recognizing the time required to implement new legislation, the Supreme Court directed Parliament to make changes within six months to the relevant provisions of the Criminal Code.

Accordingly, in November of 1991 Bill C-30 was passed by the House of Commons and implemented in February of $1992 .^{118}$ The new legislation clearly illustrates the meshing of neoliberal and welfarist approaches in responding to the "not criminally responsible on account of mental disorder" (NCRMD). Perhaps the most significant revision made was that of the language used to describe individuals found NCRMD. This change occurred at a time when neo-liberalist and neo-conservativist agendas renewed their allegiance towards implementing standards of 'self control' and 'individual responsibility' where accountability was required. By acknowledging that individuals who were suffering from mental illness were not criminally 'responsible' under section 16 (1) of the Criminal Code, Parliament attempted to decriminalize mentally ill individual's actions. ${ }^{119}$

\footnotetext{
${ }^{117}$ Canadian Charter of Rights and Freedoms. Department of Justice Canada $<$ http://laws.justice.gc.ca/en/charter/index.html> online: December 14, 2006 ${ }^{118}$ S. Davis. "Changes to the Criminal Code Provisions for Mentally Disordered Offenders and their Implications for Canadian Psychiatry" (1993) 38 Canadian Journal of Psychiatry 122 at 122.

${ }^{119}$ Ibid. at 99.
} 
In Ottawa, the effect of the new legislation in terms of the decriminalization of the mentally disordered offender can be illustrated in the $400 \%$ increase in NCRMD patients, who, in the past would have been found guilty of an offence and would have ended up on a probation order with a condition of requiring psychiatric treatment. $^{120}$

There are a number of explanations for the significant increase in NCRMD patients after the implementation of Bill C-30. First, after $R v$. Swain defence counsel were more likely to rely on this defence for their clients as a result of the new procedural protections, and second, because of an increased willingness to subject mentally ill individuals to criminal charges in the neo-liberal environment. Drawing on the arguments of Simon and Feeley I argue that the criminal justice system has implemented better methods to classify and manage large groups of offenders. The implementation of various procedural requirements, which I will outline below, enable both the mental health and justice systems to manage groups of NCRMD patients each year by assessing their level of risk to the community. Others suggest that it is in fact a progressive step and part of a decriminalization process. Dr. Bradford argues that these new procedures are similar to diversion programs, which redirect mentally disordered offenders from the criminal justice system and into the mental health system where they can access treatment and avoid the negative stereotypes associated with a criminal record. ${ }^{121}$

Furthermore, the new Criminal Code defined mental disorder as a "disease of the mind" rather than using the term 'insanity', which was not defined and perpetuated negative stereotypes associated with being mentally ill. ${ }^{122}$ These problems were

\footnotetext{
${ }^{120}$ J. Bradford. "Mentally Disordered Offenders and the Law" (1995) 40 Canadian Journal of Psychiatry. 223 at 224.

121 Ibid. at 223

122 S. Verdun-Jones, “The Insanity Defence in Canada: Setting a New Course" (1994) 17 International Journal of Law and Psychiatry 175 at 175.
} 
acknowledged years earlier in the report The Criminal Process and Mental Disorder published by the Law Commission of Canada. ${ }^{123}$ The report expressed concerns for the criminal justice system's “unclear language, improper attitudes, and the need for practical solutions to social problems" in dealing with mentally ill offenders. ${ }^{124}$ When mentally ill individuals are doubly labeled as "mad" and "bad" the Law Reform Commission argues that the stigma becomes even more pronounced and the offender is "perceived as being uniquely dangerous, and more in need of restrictive measures than either the merely mentally ill or criminal". ${ }^{125}$ As a result, the report argues that these attitudes of the mad criminal makes acceptable the "confinement and lengthy detention of mentally disordered accused or offenders in circumstances in which their "sane" counterpart would be either less severely sanctioned or released outright" ${ }^{126}$ Parliament attempted to address some of these concerns within Bill C-30. The perception of mental illness as a disease, rather than an all encompassing identity, like the word insanity portrayed, reinforced the notion of treatment and worked to remove stigmas attached to being a mentally ill offender.

\section{Assessment Orders}

A further explanation for the increased numbers of mentally ill individuals involved with the criminal justice system is attributed to the changes to the assessment provisions in the Criminal Code. Among these changes were those impacting forensic psychiatric assessment orders which are briefly outlined below in Table 2.1 and discussed in the following paragraphs.

\footnotetext{
${ }^{123}$ Law Reform Commission of Canada, The Criminal Process and Mental Disorder (Toronto: Information Canada; 1975).

${ }^{124}$ Ibid. at 17.

125 Ibid. at 14 .

126 Ibid. at 14.
} 
Table 2.1 A Comparison of the Legislative Changes Before and After the Implementation of Bill C- $30^{127}$

\begin{tabular}{|l|l|}
\hline \multicolumn{1}{|c|}{ The "Old Criminal Code" } & \multicolumn{1}{|c|}{ The "New Criminal Code" } \\
\hline $\begin{array}{l}\text { 1) Individuals who were found to have } \\
\text { committed an offence but were exempt } \\
\text { from criminal responsibility were "not } \\
\text { guilty by reason of insanity" }\end{array}$ & $\begin{array}{l}\text { Individuals who are found to have } \\
\text { committed an offence, but are exempt from } \\
\text { criminal responsibility are "not criminally } \\
\text { responsible on account of mental disorder" } \\
\text { (NCRMD) }\end{array}$ \\
\hline $\begin{array}{l}\text { 2) A "Remand for observation" could be } \\
\text { ordered if at trial or during the preliminary } \\
\text { hearing if "there is reason to believe...the } \\
\text { accused is mentally ill", }\end{array}$ & $\begin{array}{l}\text { Codifying a definition of assessment; } \\
\text { conducted by a medical practitioner of the } \\
\text { mental condition of the accused pursuant to } \\
\text { an assessment order made under S. 672.11, } \\
\text { and any incidental observation or } \\
\text { examination of the accused. }\end{array}$ \\
\hline $\begin{array}{l}\text { 3) The observation for assessment was for } \\
\text { a period of 30 days, }\end{array}$ & $\begin{array}{l}\text { limiting the duration of remand assessment } \\
\text { orders to 5 days, however, the court may } \\
\text { increase the period up to 30 or 60 days } \\
\text { where "compelling circumstances exist, }\end{array}$ \\
\hline $\begin{array}{l}\text { 4) Persons found "not guilty be reason of } \\
\text { insanity" were subject to automatic, } \\
\text { indeterminate detention at the discretion of } \\
\text { the Lieutenant Governor. }\end{array}$ & $\begin{array}{l}\text { Replacing the Lieutenant Governor Boards } \\
\text { with independent Review Boards. These } \\
\text { tribunals now take over deciding whether a } \\
\text { NCRMD acquittee should be detained, and } \\
\text { if so for how long. }\end{array}$ \\
\hline
\end{tabular}

"In the old Criminal Code, a person could be remanded for a psychiatric assessment if, at trial, "there is reason to believe...the accused is mentally ill" (S. 615) or, at the preliminary hearing, "there is reason to believe...the accused may be mentally ill ( $\mathrm{S}$. 537)". ${ }^{28}$ Critics argued that these provisions of the Code were vague and that the threshold for ordering a remand on the "possibility of mental illness" was rather low. ${ }^{129}$ Furthermore, it was purported that in-custody psychiatric assessments could be

\footnotetext{
${ }^{127}$ Verdun-Jones, supra note 120 at 178.

${ }^{128}$ Davis, supra note 18 at 122.

${ }^{129}$ R. Roesch, \& S. Golding, Competency to stand Trial. (Urbana IL: University of Illinois Press, 1980).
} 
effectively completed in less time than the 30 day duration that the old Criminal Code stipulated. $^{130}$

The new Criminal Code provisions attempt to address some of these concerns. The term "remand for observation" has been replaced by "assessment order" and the Code now stipulates a number of circumstances when an individual may be subjected to this order.
Assessments may be ordered to determine the following: 1 . whether or not the accused is unfit; 2 . whether or not the accused is not criminally responsible on account of mental disorder; 3. whether or not a mother, in the case of infanticide, was mentally disturbed; 4. where a person has been found unfit or NCRMD, what disposition to make; and 5. where the accused is convicted, whether or not a hospital order should be made. ${ }^{131}$

In addition, form 48 has been developed under S. 677 in the Code which stipulates that a judge must "specify the service that or the person who is to make the assessment, or the hospital where it is to be made". ${ }^{132}$ Although these provisions attempt to specify the purposes and conditions of an assessment order, it is still left to the discretion of the court to determine the threshold when an assessment should be conducted.

Bill C-30 also attempted to address concerns regarding the duration of psychiatric assessments. Now, for fitness assessments, S. 672.14 of the Criminal Code has reduced the assessment from 30 days to five days; however, the court may increase the period up to 30 or 60 days where "compelling circumstances exist or where the accused consents". ${ }^{133}$ At the outset of the implementation of these new provisions several forensic clinicians expressed concern about whether the additional requirements

\footnotetext{
${ }^{130}$ Davis, supra note 18 at 123 .

131 Ibid. at 122 .

132 Martin's Annual Criminal Code (Aurora: Canada Law Book inc., 2001) at 1138.

${ }^{133}$ Martin's Annual Criminal Code, supra note 127 at 1074.
} 
surrounding the use of 5 day assessments imposed inordinate financial burden and demands on the time of few forensic psychiatrists in the country". ${ }^{134}$ Many argue that the 5 day assessment is too short to conduct a detailed evaluation that may be required to assess fitness and as a result the assessment period must then be extended. Studies have found that the number of psychiatric assessments decreased immediately after the amendments to the Criminal Code were proclaimed into force but then began to increase 2 to 3 years afterwards. ${ }^{135}$ Although these new provisions intended to reduce the amount of time individuals were held in-custody for forensic psychiatric assessments, evidence suggests that these particular provisions failed to achieve their desired effects. ${ }^{136}$

Furthermore, until 1992 forensic patients were generally only those who had committed serious criminal offences. Previously, accused individuals were subject to a period of indefinite detention at the pleasure of the lieutenant governor of the Province. The implementation of Bill C-30 now required the establishment of independent Review Boards to make decisions within set time periods regarding the length of detention of accused individuals. These provisions are intended to eliminate the danger of those who are acquitted of the less serious offences from being detained for disproportionately long periods of time. ${ }^{137}$ As a result of these changes to the Criminal Code, and the criteria for detention by the Ontario Review Board, there has been an increase in supervision of persons who have committed non-violent offences, causing greater pressures on resources in the mental health system. Given that there is now no risk of indefinite detention of

\footnotetext{
134 J. Arboleda-Florez, supra note 114 at 226.

135 J. Livingston et. al. "A Follow-Up Study of Persons Found Not Criminally Responsible on Account of Mental Disorder in British Columbia" (2003) 48 Canadian Journal of Psychiatry. 408 at 409.

136 Ibid. at 409.

${ }^{137}$ Verdun-Jones, supra note 120 at 180.
} 
mentally ill individuals found NCRMD, and a greater likelihood for diversion and community living, lawyers are more likely to raise the defence on behalf of their client.

Studies suggest that the post-1992-forensic psychiatric system is serving a segment of the population that may not fit within the traditional mental health and criminal justice systems. ${ }^{138}$ Livingston's study, conducted in British Columbia, found that there were a greater number of the NCRMD cohort who were "charged with relatively minor index offences, such as assault - and nuisance-type, and fewer individuals [who] were charged with more serious index offences, such as murder and attempted murder."139 Forensic psychiatrist, Dr. Bradford, reported that this is also the case in Ottawa. ${ }^{140}$ As outlined above, since counsel are more likely to raise the issue of criminal responsibility the criminal justice system is seeing a greater number of individuals who have committed a variety of offences. As a result, increased demands are placed on the mental health system to accept responsibility for their care.

An additional factor contributing to the increased pressures on resources within the forensic system is the fact that although there is a presumption against in-custody assessment orders under section 672.14 of the Criminal Code, an overwhelming number of fitness assessments are conducted in custody. ${ }^{141}$ One study reported that $75.1 \%$ of initial fitness assessments were conducted in a forensic psychiatric hospital and $22.9 \%$ were completed in other in-custody facilities". ${ }^{142}$ Although these mentally ill clients are difficult to manage in the community, there is a neo-liberal reluctance to implement

\footnotetext{
${ }^{138}$ For a detailed description of these studies see Livingston's "A Follow-Up Study of Persons Found Not Criminally Responsible on Account of Mental Disorder in British Columbia" and Smith J. "Amendments to the Criminal Code of Canada: Impacts on Inpatient psychiatric remands" 1993.

${ }^{139}$ Livingston, supra note 133 at 414.

${ }^{140}$ Bradford, supra note 118 at 224.

${ }^{141}$ Martin's Annual Criminal Code, supra note 130 at 1074.

${ }^{142}$ Livingston, supra note 133 at 411.
} 
necessary community mental health resources resulting in increased pressures on the mental health system. As a result, individuals wait in correctional institutions, which are both ill-suited and ill-equipped to respond to their needs, for indeterminate periods of time until a forensic bed in a psychiatric facility becomes available.

In 2004, the Health System's Research and Consulting Unit (HSRCU) at the Centre for Addiction and Mental Health (CAMH) ${ }^{143}$ published a study of inpatients and outpatients receiving mental health services in Central East-Penetanguishene, Central East-Whitby, Northwest and Toronto-Peel regions. Koegl and colleagues worked closely with nine Ontario provincial psychiatric hospitals and eight community mental health implementation task forces to collect data on over 53,000 adult clients enrolled in formal community mental health services. ${ }^{144}$ Their research recognized that a sizable portion of individuals suffering from mental illness could be effectively treated in the community, however, what was not known was whether the community mental health system was positioned to respond to the needs of this population. ${ }^{145}$ The report clearly outlined an operational framework based on five different levels of care (based on assessed need), ranging from level one (least intensive), to level 5 (most intensive). Interestingly, the fourth level of care, which is described as

appropriate for individuals who need daily support, whose behaviours make it difficult for them to live independently, and who may at times need a secure environment. On-site staff provide supervision and rehabilitation supports, and may also provide clinical services. Specialized services may be needed for

\footnotetext{
${ }^{143}$ The Centre for Addiction and Mental Health was formed in 1998 as result of the merger of the Clarke Institute of Psychiatry, the Addiction Research Foundation, the Donwood Institute and Queen Street Mental Health Centre. The central facilities are located in Toronto, as well as 26 community locations throughout the Province of Ontario. Online: < http://www.camh.net/About_CAMH/index.html >.

${ }^{144} \mathrm{Koegl}, \mathrm{C}$. et. al. "Mental Health Services in Ontario: How well is the province meeting the needs of persons with serious mental illness?" Centre for Addiction and Mental Health online: www.camh.net/hsrcu 20061 at 6 .

145 Ibid. at 7 .
} 
specific sub-groups such as...forensic clients who have security needs related to their legal status,

does not formally exist in Ontario as outlined by the operational framework "Making it Happen" for the delivery of mental health services (1999). ${ }^{146}$ Koegl and colleagues estimate that $39 \%$ of individuals could be serviced in the community in Residential Treatment settings if such services were available in Ontario. ${ }^{147}$ This operational framework, which is still being utilized today, is intended to set out guidelines to ensure mental health services are comprehensive, coordinated and provided based on consumer needs and best practices. ${ }^{148}$

The analysis of information collected in Koegl's study revealed that there was a fairly large degree of mismatch between recommended and current levels of communitybased support services across Ontario. Their study revealed that $47 \%$ of court support clients needed at least weekly contact with community mental health services and only $2 \%$ were receiving it. ${ }^{149}$ Further data from this study showed that more than $50 \%$ of clients were receiving less care than they needed. The guidelines in "Making it Happen" assert that the model of care provided in level three should consist of Assertive Community Treatment Teams (ACTT). The authors of this framework argue that these program models have proven success in working with this population and will also serve to reduce pressures on the forensic system. However, the analysis revealed that clearly there is a need to implement more of these ACTT program models across Ontario to service level three individuals as $32 \%$ were assessed as needing daily support (Level 3

\footnotetext{
${ }^{146}$ Ibid. at 9.

${ }_{147}$ Ibid. at 13.

${ }^{148}$ Making it Happen: Operational Framework for the Delivery of Mental Health Services and Supports" Ontario: Queen's Printer for Ontario; 19991 at 2.

${ }^{149} \mathrm{Koegl}$, supra note at 142 .
} 
Care) and only $11 \%$ were actually getting it. ${ }^{150}$ The study estimates that a further 500 inpatients and 2700 provincial psychiatric hospital outpatients would benefit from ACTT or some form of intense case management services. ${ }^{151}$ Of significance is that this study also showed that when offenders had access to outpatient psychiatric treatment and community mental health services, including housing, there was a dramatic reduction for demand for fitness assessments and treatment orders. ${ }^{152}$ At the same time, there was an increase in the number of bail orders, diversion, and probation orders.

It is clear that the operational framework for the delivery of mental health services outlined in "Making it Happen" is valuable and that mentally ill individuals should be cared for, where possible, in the community, however this study illustrates that we must first ensure we are able to provide appropriate levels of program service and support.

\section{Outcry for Government Support}

Evidence of the surfacing problems between the interface of the criminal justice system and the mental health system began to gain political, legal and media momentum throughout the 1980s and 1990s. In April of 1990 former Ontario Corrections Minister, Richard Patten, reported to the Ottawa Citizen that "between 15 and 20 percent of prisoners in provincial jails [had] psychiatric problems" and expressed the need for more treatment facilities in Ontario. ${ }^{153}$ Furthermore, in 1998 Member of the Provincial Parliament, Mr. Michael Gravelle, pleaded with the Minster of Health during a debate reported in the Ontario Hansard to recognize the crisis in the delivery of mental

\footnotetext{
${ }^{150}$ Ibid.

151 Ibid.

152 Ibid.

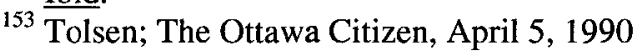


healthcare in Ontario and called on immediate action to deal with the situation. ${ }^{154}$ In addition, Gravelle addressed the shortage of psychiatric beds and psychiatrists to adequately respond to the needs of mentally ill individuals. In response to Mr. Gravelle's pleas the former Minister of Health and Long-Term Care, the Honourable Elizabeth Witmer, assured Mr. Gravelle that

we, [the Ontario Government], have been moving forward in that regard now for the last number of years. What we've been endeavoring to do is ensure we have a system that is integrated, that provides hospital beds when necessary, but that we also give people the opportunity to live in the community. ${ }^{155}$

This debate is indicative of the lack of Government funding and attention which was needed to properly implement community resources when mentally ill individuals were discharged from hospitals into the community beginning in the 1960's.

Despite Government assurance that the mental health crisis was under control, the problem continued to plague both the criminal justice and the mental health systems. In $2000 \mathrm{CAMH}$ made a number of specific recommendations during proceedings under the Standing Senate Committee on Legal and Constitutional Affairs to alleviate the problems facing the Ontario government regarding the lack of available psychiatric beds for incustody assessments. They suggested that "sections 672.11 and 672.13 [of the Criminal Code] be amended to require the consent of the person in charge of the hospital where the accused is to be assessed before the order can lawfully be made by a court". ${ }^{156}$ Currently there is no obligation on behalf of the judge to ascertain whether there is a bed available before making an assessment order and directing the accused to be taken to hospital. As

\footnotetext{
${ }^{154}$ Ontario Hansard Debate: May 13, 1998, Retrieved March 5, 2006 online: http:/hansardindex.ontla.on.ca/hansardeissue/36-2/1012a.htm

155 Ibid.

${ }^{156}$ Centre for Addiction and Mental Health "Submission to the Standing Committee on Justice and Human Rights on Mental Health Provisions of the Criminal Code" Toronto: November 26, 2006 at 2.
} 
a result, there may be a list of 15 individuals waiting at the detention centre for a hospital bed. This demonstrates that although theorists contend that we are living in a contemporary neo-liberalist society Judges are still operating under welfarist ideals. In order to provide mentally ill individuals with an integrated system of care members of the justice system must be cognizant of the availability of resources. CAMH also suggested that subsection $672.14(1)$ and (2) of the Code be amended to require that no assessment will be for a period in excess of five days. ${ }^{157}$ Furthermore, they highlight that an additional strain on forensic resources occurs where the assessment has been completed well in advance of the return date stipulated on the Form 48, and the accused could be returned back to court on an expedited basis, but there is no practical legal mechanism for a facility to return the accused person to court. ${ }^{158}$

CAMH recommended that section 672.14 be amended to require that a person be returned to the court immediately upon completion of the assessment.

Before considering the current assessment practices occurring in Ottawa it is important to appreciate the limitations on assessment orders, particularly when they occur early on in the criminal process. One Toronto Crown Attorney argues that "it is very easy for confusion to develop between the perceived need for information about the accused's mental condition in order to make the necessary decisions respecting the processing of charges (the reason why the assessment should be ordered in the first place) and the understandable desire of professionals to treat that mental condition and thus improve the accused's health". ${ }^{159}$ He cautions the members of the medical profession to be cognizant of the three provisions of the Criminal Code:

\footnotetext{
${ }^{157}$ Ibid. at 3 .

158 Ibid. at 2.

${ }^{159}$ E. Siebenmorgen, "Assessment Orders Under Part XX.I of the Criminal Code: The Current Environment” (Toronto: April 2006) at 5.
} 
S. 672.1 - the definition of assessment;

S. 672.19 - the prohibition on ordering treatment; and

S. 672.191 - the return of the accused to court upon completion of the assessment. An assessment as defined under Section 672.1 of the Code means simply an assessment of the mental condition of the accused pursuant to an assessment order, and any incidental examination or observation of the accused. Section 672.19 states that no assessment order may purport to authorize the administration of treatment of any psychiatric treatment of the accused. This does not mean that the accused may not receive any treatment during the assessment period; rather, it only means that any treatment administered must be pursuant to other (provincial) legislature and cannot be authorized under the criminal law. Finally, this Crown argued that one must always keep in mind the nature of Section 672.191 which requires that an accused be brought back to court as soon as practicable upon completion of the assessment and, in any event, by the end of the period that the order is in force.

When interviewing Dr. Helen Ward, forensic psychiatrist and Director of the Forensics Service Program at the Royal Ottawa Mental Health Centre (ROMHC), who conducts assessment orders with individuals who have been ordered by the court under Section 672.11 for an assessment, I asked about practices with regard to this matter. ${ }^{160}$ Acknowledging Section 672.191 she indicated that the practices varied according to jurisdiction but that her general approach was to keep the accused at the hospital for the duration of the order so that they could improve the accused's condition before sending her back to jail. Dr. Ward stated that because the threshold for fitness is so low, a person

\footnotetext{
${ }^{160}$ In the interest of protecting anonymity some of the interviewees, names, places and dates have been changed or omitted.
} 
can still be suffering from a mental illness but be considered fit by the court. ${ }^{161}$ By using the entire assessment period individuals can be screened, consent can be obtained to administer medication, and the psychiatrist can return to court with an opinion of fitness, recommendation of NCRMD and a discharge plan. Dr. Ward argues that by keeping the accused for the duration of the assessment we can reduce the rates of recidivism and the mental health burden on the individual and his/her parents. ${ }^{162}$

An Ottawa criminal defence lawyer supported this practice outlined by Dr. Ward stating that "although I have not seen empirical studies, once persons are hospitalized, fully assessed and connected with a social worker, ACT team, and access to supervised living, [in my experience] rarely will they come back to the criminal justice system or hospital, usually once sufficient supports are in place". ${ }^{163}$ This criminal defence lawyer did recognize that this method of dealing with accused individuals who have been ordered for an assessment may cost more; however, he argued that there are greater savings in the long run. "In Ottawa, there are real efforts made to connect the individual with the community and establish a network for that individual". ${ }^{164}$

Conversely, the opinion of a member of the Ministry of Health and Long-term Care (MOHLTC) regarding this issue was quite different. In fact, this individual condemned the practice of holding accused at the hospital for the duration of their assessment, which he commented has developed here in Ottawa, and indicated that it is this very practice which is at least in part responsible for the backlog the Ottawa forensic

\footnotetext{
${ }^{161}$ Interview of Dr. Helen Ward (10 November, 2006)

162 Ibid.

${ }^{163}$ Interview of Ottawa Criminal Defence Lawyer November 2006.

164 Ibid. at 2.
} 
system is currently experiencing. ${ }^{165}$ The member of the MOHLTC acknowledged that although the psychiatrist's concern for the mentally ill individual may be valid, it is the court that should be making the decision to implement a treatment order. This individual highlighted the cost inefficiency of this practice in Ottawa and indicated that a one day stay in the forensic unit would be about $\$ 700.00$ versus a fitness assessment conducted at the court by a psychiatrist in one hour as is done in some other jurisdictions. He went on to say that "individuals in hospitals may be good, however, hospitals are not good at case management. They are generally not aware of what's outside their four walls". ${ }^{166}$

Interestingly, I also had the opportunity to sit down with Wendy Stewart, a professional social worker who has been working at the in-patient assessment and stabilization unit for court ordered psychiatric assessments at the ROMHC for the past seven years. Ms. Stewart described much of her daily responsibilities to include working with the accused's family, community supports such as case management services, and locating appropriate housing when needed, in order to develop a contingency plan for the possible discharge of the accused individual. She also routinely advocates on behalf of mentally ill individuals with many organizations including: hospitals, social assistance programs, such as the Ontario Disability Support Program, landlords and many other members of the healthcare system. Ms. Stewart demonstrated that the hospital was quite aware of the various community supports and the importance of networking with these agencies to access resources for the patients and accelerate the formulation of an appropriate discharge plan.

\footnotetext{
${ }^{165}$ Interview of Member of the Ministry of Health and Long-term Care (2006).

${ }^{166}$ Ibid.
} 
The article, “Reality, Ontario's Mental Health System isn't Working”, published by the Ontario Public Service Employees Union (OPSEU) in 2002 highlights the urgency of addressing this issue and the need to increase the number of secure forensic beds. OPSEU directed the Government to "increase forensic beds in psychiatric hospitals to alleviate the wide-spread problem of the mentally ill being in our jails and correctional centres". ${ }^{167}$ Given both the seriousness and magnitude of this issue, the report also makes a number of positive recommendations to respond to the problem. Some of these recommendations include: access to mental health services, available emergency psychiatric staff, and legislating and enforcing quality mental health services. ${ }^{168}$ This report is significant because it acknowledges that the solution to the problem extends beyond simply increasing the number of forensic psychiatric beds, but also highlights the importance of extending community mental health services.

Furthermore, in 2002 an Ontario Court judge told a conference of Ottawa-area lawyers that "the Ontario government could have a death on its hands because mentally disturbed people are being jailed for weeks before they can be moved to overburdened psychiatric facilities to have their fitness to stand trial assessed". ${ }^{169}$ No more than one year later 59 year old, James O’Brien, suffering from schizo-effective disorder, including paranoia, delusions and hallucinations, died at the Ottawa-Carleton detention centre while waiting for an assessment at the Royal Ottawa Hospital. ${ }^{170}$ Although the problem

\footnotetext{
${ }^{167}$ OPSEU; 2002, Retrieved March 13, 2006 online: http://www.opseu.org/news/press2002/mental\%20health\%20report\%20web\%20version.pdf $\frac{1}{168}$ Ibid.

${ }^{169} \mathrm{C}$. Schmitz, "Shortage of psychiatric beds poses risk of jail hanging, judge tells the conference" 22 The Lawyers Weekly (Montebello Conference: Quebec; December 13, 2003).

${ }^{170}$ The Ottawa Citizen Editorial "Beds, not Jail, for mentally ill” January 18, 2005.
} 
persists, these reports served to facilitate public awareness and placed pressure on the Government to act immediately to address the issue.

Although the changes resulting from the implementation of Bill C-30 was a greater recognition of the mentally ill offender, the lack of resources to serve this individual within the community continued to surface. Perhaps in response to the growing media and political attention which was gaining momentum the MOHLTC released "Making it Happen: Operational Framework for the Delivery of Mental Health Services and Supports" in 1999 which featured a policy framework for specialized forensic services (among other things). By charting these changes we can better understand the impacts they have had on the current operations with mentally ill individuals.

\section{Conclusion}

When looking at the interface of the mental health and criminal justice systems it is apparent that neoliberal and welfarist approaches are operating concurrently with one another on mentally ill offenders. Although the new Criminal Code provisions have contributed to the decriminalization of mentally ill offenders it is important to consider the backdrop of social and political influences on changes made within the justice system. The implementation of Bill C-30 by Parliament demonstrates the movement towards a system which is interested in capitalizing on neoliberalist methods of classification and management of large groups of offenders. The significant increase in individuals found NCRMD after 1992 is evidence that these changes are effectively working to fulfill new political ideologies. Meanwhile, judges, who are not governed by the same political policies as parliament, continue to make decisions rooted in welfarist ideals without 
considering the availability of resources. Systems of accountability need to be implemented to ensure that the mental health and justice systems are working in collaboration with one another to provide an integrated service to mentally ill offenders. 


\section{Chapter 3: Jailing the Mentally Ill Unconstitutional: R v. Hussein \& Dwornik}

\section{$\underline{\text { Introduction }}$}

The policy shifts occurring during the $20^{\text {th }}$ century here in Canada, and other jurisdictions, from the institutionalization of people with mental illness to a system that depends on community based mental health services is frequently referred to as mental health reform. Over the past twenty years 20 reports have been issued in the Province of Ontario supporting real investment into these programs; however, many argue that this investment has not yet taken place. As a result, increased pressure has been placed on the criminal justice and mental health systems to respond to the specialized needs of these individuals. The message of civil rights groups, members of the medical association, media, the legal community, and academics is clear; there is an imminent need to increase funding so that more forensic assessment beds may be purchased and community resources implemented to alleviate the wait times of accused mentally ill individuals waiting to be assessed. Although this problem had become very clear to the courts, before 2004 no Judge had made an official ruling regarding this issue. The case of $R v$. Hussein and Dwornik highlighted the need for the courts to respond to a specific problem arising out of the lack of available mental health resources. Despite the declaration made by Ottawa Superior Court Judge, Justice Desmarais, ordering the government to make swift changes within six months of his ruling, the problem still persists today. Many criminal defence lawyers draw on legal remedies, such as Habeas corpus applications, to alleviate the problem for their clients. However, although this remedy effectively reduces the wait times for their client, the practice raises a number of ethical questions with regards to others on the waiting list. 
Since the decision of Justice Desmarais was handed down in 2004 the Provincial government has attempted to make some changes to address the crisis at the interface of the mental health and the criminal justice systems. Firstly, there have been a number of funding announcements, however, it appears that many of these announcements refer to the initial $\$ 65$ million commitment which was announced in June of $2004 .^{171}$ Furthermore, the Ontario Ministry of Health and Long Term Care has sought to enhance systems of information sharing within the province to develop a region-wide centralized bed registry to address the problem. Despite these attempts by the Ontario government the problems continue to persist here in Ottawa.

\section{$\underline{R}$ v. Hussein and Dwornik}

In 2004 the courts responded to a specific problem arising out of the lack of available mental health resources. After being charged with a criminal offence, many mentally ill individuals are ordered by the court to undergo an assessment of their mental condition pursuant to section 672.11 of the Criminal Code of Canada. The applicable portions of that section read as follows:

672.11 A court having jurisdiction over an accused in respect of an offence may order an assessment of the mental condition of the accused, if it has reasonable grounds to believe that such evidence is necessary to determine

(a) whether the accused is unfit to stand trial;

(b) whether the accused was, at the time of the commission of the alleged offence, suffering from a mental disorder so as to be exempt from criminal responsibility by virtue of subsection $16(1) \ldots{ }^{172}$

However, given the lack of psychiatric beds available at the ROMHC individuals are detained in custody up to the time of their assessment. Sections 672.14 and 672.15 of the

\footnotetext{
171 "Re-Announced Funding Does little to keep mental health patients out of jail" Ontario Public Service Employees Union (OPSEU) January 13, 2006.

${ }^{172}$ Martin's Annual Criminal Code, supra note 130 at 1072.
} 
Criminal Code of Canada outline the timelines available for assessment orders to be carried out, but do not govern the procedure allowing individuals to be detained in prison awaiting an assessment. Section 672.14 reads as follows:

(1) An assessment order shall not be in force for more than thirty days.

(2) No assessment order to determine whether the accused is unfit to stand trail shall be in force for more than five days, excluding holidays and the time required for the accused to travel to and from the place where the assessment is to be made, unless the accused and the prosecutor agree to a longer period not exceeding thirty days.

(3) Notwithstanding subsections (1) and (2), a court may make an assessment order that remains in force for sixty days where the court is satisfied that compelling circumstances exist that warrant it. $^{173}$

Section 672.15 governs extensions of an assessment order.

672.15(1) Subject to subsection (2), a court may extend an assessment order, of its own motion or on the application of the accused or the prosecutor made during or after the period that the order is in force, for any further period that is required, in its opinion, to complete the assessment of the accused.

(2) No extension of an assessment order shall exceed thirty days, and the period of the initial order together with all extensions shall not exceed sixty days. ${ }^{174}$

Due to a shortage of beds in the forensic unit at the ROMHC a practice has evolved whereby individuals are held in jail while awaiting their assessments. ${ }^{175}$

In the 2004 case of $R v$. Hussein and Dwornik, counsel for the applicants argued that this practice deprives accused persons of their right to liberty thereby infringing on Section 7 and 9 of the Canadian Charter of Rights and Freedoms. Both Mr. Hussein and Mr. Dwornik had been ordered by the court to undergo psychiatric assessment.

\footnotetext{
${ }^{173}$ Martin's Annual Criminal Code, supra note 130 at 1074.

${ }^{174} \mathrm{R}$ v. Hussein and Dwornik, supra note 2 at para. 5.

175 Ibid. at para 7.
} 
Mr. Dwornik was ordered to be assessed by a court of competent jurisdiction on January 13, 2003. He was detained at the Regional Detention Centre from that date until February 13, 2003, a period of thirty-two (32) days before the assessment actually commenced. ${ }^{176}$

Similarly, Mr. Hussein spent a period of twenty-nine days in custody at the Regional Carleton Detention Centre, in 2003, before receiving a psychiatric assessment. ${ }^{177}$ The amount of time an individual spends in custody is directly dependant upon the availability of a bed at the ROMHC. Accused mentally ill individuals must wait until their name has reached the top of the priority list and a bed becomes available, before being transferred from the jail to the forensic unit. ${ }^{178}$ "In some cases, accused persons who are presumed to be innocent may be detained for longer periods of time than any potential penalty they would have received after a finding of guilt". ${ }^{179}$

The hardships endured by both Mr. Hussein and Mr. Dwornik while incarcerated enable us to recognize the seriousness of this issue and its relevance in the broader context of human rights in Canadian jails. While incarcerated, mentally ill individuals could potentially endure physical violence or the threat of physical violence, inordinate amounts of stress, combined with fear, difficulty in receiving proper treatment, and isolation. $^{180}$ When interviewing forensic psychiatrist, Dr. Ward, I asked her what impacts, if any, accused individuals described while incarcerated at the Ottawa Carleton Detention Centre. ${ }^{181}$ Dr. Ward indicated that approximately $30 \%$ to $40 \%$ are not affected by the experience, and a further $20 \%$ to $30 \%$ actually incorporate the environment of the

\footnotetext{
${ }^{176}$ R v. Hussein and Dwornik, supra note 2 at para 8.

177 Ibid. at para 5.

${ }^{178}$ Ibid. at para 5.

${ }^{179}$ Ibid. at para 5 .

${ }^{180}$ Ibid. at para 5.

${ }^{181}$ Dr. Helen Ward, supra note at 159.
} 
jail into their illness through symptoms such as hallucinations. She went on to say that for an additional $20 \%$ to $30 \%$ of the assessment order population, the psychological trauma of being in prison actually worsens their illness. This segment of the group have often never been to jail before and will tell her for years afterwards how traumatized they were by the experience. ${ }^{182}$ Some of the incidents these individuals have cited as examples of their traumatic experiences include: being refused tampons, being made fun of, strip-searched, having their food stolen, and being harassed by other inmates who are demanding to know why they are there because they often assume they are sex offenders. ${ }^{183}$ According to Dr. Ward the illness of the remaining $10 \%$ of this population is made significantly worse by the experience of being incarcerated while awaiting an assessment bed. Members of this group suffered from severe psychosis at the time of their incarceration, and as a result posed significant risk to themselves. Often these individuals engage in risky behaviours that are not necessarily recognized by the guards as mental illness driven. As a result, these individuals are often punished for these behaviours. One example Dr. Ward recalled involved

an individual who was manic and placed in the segregation unit while on suicide watch. ${ }^{184}$ During this time he was feeling really cold and in his crazed state of mind his solution to feeling cold was to flood the cell with hot water. In time, obviously, the water became cold, but the guards basically just left him with it. ${ }^{185}$

\footnotetext{
${ }^{182}$ Dr. Ward. supra note at 159.

${ }^{183}$ It should be noted that the individuals in the prison environment view sex offenders, or those suspected of committing a sex offence, as the worst type of inmates and as a result they are often segregated, beaten, and harassed by fellow inmates.

${ }^{184}$ Manic has been defined by the Royal Ottawa Health Care group as a distinct period during which there is an abnormally and persistently elevated, expansive or irritable mood. This period of abnormal mood must last at least one week. Online: Royal Ottawa Health Care Group $<$ http://www.rohcg.on.ca/resources/glossary-e.cfm?strSearch=manic $>$.

${ }^{185}$ Dr. Ward, supra note at 159.
} 
These examples serve to illustrate that the experiences of incarceration are exacerbated for mentally ill individuals and may contribute to an increase in the severity of their mental health problems.

In addition to the traumatic experiences the mentally ill go through while being incarcerated, they must also be subject to the unacceptable conditions of detention centres. In the case of $R$ v. R.L.L., heard before the Ontario Superior Court, defence counsel argued that the pre-trial custody served by his client should count on a ratio of three to one given his serious concerns regarding the ability of the Ottawa Carleton Detention Centre to provide appropriate accommodations for accused individuals. $\mathrm{He}$ submitted that "although we are quick in this country to criticize the penal systems and detention centers in other parts of the world, especially the third world, it is not inconceivable that in the capital city of this great country conditions are deplorable". ${ }^{186}$ Given the crowded conditions of the Ottawa Carleton Detention Centre it is not uncommon that accused are expected to sleep three or four persons in a two person cell. The decision of Power $\mathbf{J}$ provided a lengthy commentary outlining his utter disapproval of the conditions of the Ottawa detention centre as follows:

The evidence heard by me in this matter leads me to the inescapable conclusion that the Regional Detention Centre in this area is not adequate for the purpose for which it is intended to serve. The overcrowding is unacceptable, especially in circumstances where other Eastern Ontario detention establishments are being closed and inmates directed to the Ottawa location.

Adequate recreation and exercise opportunities must be available to the inmates. Inmates must not be placed in maximum-security areas or hospital areas or indeed, in other facilities not designed to meet the special problems which these inmates face. Decisions must be made on the basis of providing appropriate

${ }^{186}$ R v. R.L.L. [2004] O.J. No. 3604 (Ont. Sup. Ct) at para 6. 
accommodation rather than the decisions being driven by whatever inadequate facilities are available...

Finally, in my opinion, the overcrowding at the Regional Carleton Detention Centre brings the administration of justice into disrepute. $^{187}$

Based on the evidence from defence counsel regarding the conditions of the detention centre Justice Power granted the accused individual three for one credit for his presentence custody.

Even though all human rights issues are important, the mentally ill are a marginalized population whose rights should be protected. In the case of $R v$. Hussein and Dwornik Justice Desmarais found that the practice of detaining accused individuals awaiting an assessment is contrary to the relevant provisions of the Criminal Code of Canada, offends section 7 and 9 of the Canadian Charter of Rights and Freedoms and directed the Government to make swift changes within six months of the decision. ${ }^{188} \mathrm{~A}$ decision was made by the Ontario Ministry of the Attorney General not to appeal the declaration of unconstitutionality so the order of Justice Desmarais remains in full force and effect. ${ }^{189}$ Since the decision was handed down in 2004 there have been very few significant changes which get at the crux of this issue. The rights of the mentally ill continue to be violated while they are unjustly detained in custody.

\section{Prerogative Remedies for Mentally Ill Offenders}

In response to the crisis presented by the lack of available beds for forensic psychiatric assessments, Ottawa defence counsel were urged at a Criminal Lawyer's conference to utilize legal remedies, such as habeas corpus applications, which are

${ }^{187}$ R v. R.L.L. supra note 184 at para 8.

188 Ibid. at para 5 .

189 J. Obagi,\& E. Quiqley, "Mental Health Assessments - Jailing the Mentally Ill Pending Assessment" (2006) Ottawa at 5. 
entrenched in subsection 10(c) of the Canadian Charter of Rights and Freedoms and outlined in S. 774 - 784 of the Criminal Code of Canada, to pressure the government to provide more forensic beds. ${ }^{190}$ Habeas corpus can be defined as "a writ having for its object to bring a party before a court or judge; especially, one to inquire into the cause of a person's imprisonment or detention by another, with the view to protect the right to personal liberty...". ${ }^{191}$ In accordance with the Superior Court of Ontario criminal proceedings rules, a habeas corpus application first requires a date to be obtained with the registrar and notice in writing provided to all parties at least "two clear days prior to the date fixed for the hearing". ${ }^{192}$ Since a habeas corpus application is issued for cause shown, it is usually grounded in an affidavit sworn by the accused, or an individual who is aware of the issue. The application for a writ of habeas corpus is traditionally a two stage process, however, the usual practice in most provinces is to collapse them into one. In the first stage "the applicant must establish that he is in detention; assert the cause or basis for his detention; complain that his detention is unlawful and establish that there are probable and reasonable grounds for his complaint". ${ }^{193}$ If such grounds are present, "the writ's issues and merits are determined on the return of the writ". ${ }^{194}$ The judge hearing the matter may order the "continued detention of the applicant and direct the judge or other judicial officer, under whose process the applicant is detained, to do such other thing, or hear such evidence as will best further the ends of justice". 195

\footnotetext{
${ }^{190}$ Schmitz, supra note 167 at 2.

${ }^{191} \mathrm{~S} 279475$

${ }^{192}$ Superior Court of Ontario, Criminal Proceedings Rules. Online at: $<$ http://www.ontariocourts.on.ca/superior_court_justice/rules/rules.pdf>. ${ }^{193}$ Idziak v. Canada (Minister of Justice) (1989) 53 C.C.C. (3d) 464

${ }^{194}$ R v. Olsen [1989] 1 S.C.R. 296

${ }^{195}$ Martin's Annual Criminal Code, supra note 127 at 1342.
} 
One Ottawa criminal defence lawyer commented that as soon as a habeas corpus application is scheduled to be brought before the court the bed mysteriously appears, although the hospital denies a relationship between bringing the application and the finding of a bed. ${ }^{196}$ In this lawyers' opinion it seems too coincidental. Another Ottawa lawyer stated that there are many cases when the application is not effective because individuals are often in hospital at the time the application is heard making the habeas corpus application moot. ${ }^{197}$ As outlined above, defence counsel must give notice to the court, and the Crown Attorney's Office before bringing an application before the court, often creating enough delay for the accused to be transferred to the hospital. In addition to these procedural issues, habeas corpus applications raise a number of ethical concerns. An Ottawa criminal defence lawyer drew on the example of $R v$. Kurd to highlight some of these problems. Mr. Kurd suffers from chronic schizophrenia and was ordered by Justice Roy on January 18, 2005 to be detained at the Royal Ottawa Hospital pursuant to section 672.29 of the Criminal Code on the grounds that his fitness to stand trial might be compromised if he were to be detained in custody. ${ }^{198}$ On April 26th and $27^{\text {th }}$ circumstances arose in which the 12 beds in the Royal Ottawa Hospital secure facility, in which Mr. Kurd was being detained, were all full. ${ }^{199}$ At the same time a young woman was being detained at the Ottawa Carleton Detention Centre in custody and awaiting a court ordered assessment. Faced with a habeas corpus application that her constitutional rights were being violated by delay in admitting this inmate to the Royal Ottawa Hospital,

\footnotetext{
${ }^{196}$ Interview of Ottawa Criminal Defence lawyer. Supra note at 157.

197 "A proceeding is moot when a decision will not have the effect of resolving some controversy affecting the rights of the parties. A live controversy must be present not only when the proceeding is commenced, but also when the court is called upon to reach a decision." Pinet v. Penetanguishene Mental Health Centre [2006] O.J. No. 678 at para 46 (O.S.C).

${ }_{198}^{R}$ v. Kurd. [2005] O.J. No. 2794.

199 Ibid. at para 15.
} 
Mr. Kurd was removed from the hospital and returned to the detention centre in contravention of Justice Roy's order. ${ }^{200}$ Justice Rutherford, who heard the application by the accused for an order returning him to the Royal Ottawa Hospital in Superior Court on June 29,2005 , found that there had been no authority to remove Mr. Kurd from the hospital and ordered that he be returned there to await trial. ${ }^{201}$ This criminal defence lawyer describes the Ontario Mental Health system as one that is put together with bandaids and elastics. "Effectively what happens is that when a space opens up in one area, it then in turn closes in another, creating additional problems which must then be dealt with". 202

Some judges have also begun making orders that an accused be taken "forthwith" to the hospital for a psychiatric assessment, even after ascertaining that there are no beds available for the accused person. ${ }^{203}$ As a result, the individual who is the subject of the "forthwith order" is pushed to the front of the queue, while the other individuals are bumped down to the end of the waiting list. Although this order ensures that this particular individual will receive expeditious care, it also raises a number of concerns regarding the care of those who have been waiting at the detention centre for lengthy periods of time, and who are now passed over.

Several other Ontario courts have upheld the decision of Justice Desmarais in $R v$. Hussein and Dwornik and have criticized the Ontario government for their failure to

\footnotetext{
${ }^{200}$ Ibid. at para 15.

201 Ibid. at para 1.

202 Interview of criminal defence lawyer, supra note at 161 .

${ }^{203}$ Centre for Addiction and Mental Health, supra note 154 at 4.
} 
provide mentally ill individuals with access to adequate facilities. ${ }^{204}$ In the case of Orru v. Penetanguishene Mental Health Centre an application was brought by Mr. Orru for a declaratory judgment by way of a Habeas corpus ad subjiciendum with certiorari in aid. $^{205}$ In $1998 \mathrm{Mr}$. Orru was found NCRMD and was detained at the maximum security Mental Health Centre in Penetanguishene. When a person has been found NCRMD the Ontario Review Board must conduct an annual review of the person so long as the person remains at a mental health institution. ${ }^{206}$ In July 2004, the Ontario Review Board ordered that Mr. Orru be transferred to a medium secure facility in Brockville; however, Brockville would not accept the transfer due to lack of available space. "Facilities are required to abide by the procedure established under the Criminal Code, and the Province has a legal obligation to provide sufficient space to meet its legal obligations to persons found not criminally responsible". ${ }^{207}$ Justice Glass found that Mr. Orru's continued detention at a maximum secure facility violated his section 7 Charter rights and ordered him to be transferred to Brockville within 15 days.

In Pinet v. Penetanguishene Mental Health Centre Mr. Pinet, who had also been found NCRMD and ordered by the Ontario Review Board to be transferred from a maximum secure facility to a medium secure institution, waited over 11 months due to lack of bed space. When Mr. Pinet brought an application before the court seeking declaration that his Section 7 and 9 Charter rights had been violated in a manner contrary to the principles of fundamental justice, the Ministry of Health (MOH) submitted that the

\footnotetext{
${ }^{204}$ See $\underline{R} v$. Kurd [2005] O.J. No. 2794. (O.S.C), Orru v. Penetanguishene Mental Health Centre [2004] O/J/ No. 5203 (O. S.C.). and Pinet v. Penetanguishene Mental Health Centre [2006] O.J. No. 678 (O.S.C). ${ }^{205}$ Ibid. at para. 5.

${ }^{206} \underline{\mathrm{R} v}$. Kurd, supra note 202 at para 18.

${ }^{207}$ Ibid. at para 1 .
} 
order was moot because Mr. Pinet had already been transferred in accordance with the

Order of the Review Board. ${ }^{208}$ To the contrary Justice Tomaso argued that

to agree with the MOH's position that Mr. Pinet's transfer is now moot would be seen as approval by this court and what happened to Mr. Pinet while he languished for $11 \frac{1 / 2}{2}$ months at Penetanguishene waiting for transfer on some unspecified date was no longer of any account... Such a position taken by the MOH is absolutely and fundamentally wrong. It reflects a mind-set which suggests to this court that the $\mathrm{MOH}$ is only prepared to deal with these types of cases on a "squeaky wheel" or "piece meal" basis... What happened to Mr. Pinet was an injustice that this court condemns in the strongest possible terms. ${ }^{209}$

Justice Tomaso went on to say that he "whole-heartedly" agreed with the comments made

by Justice Glass in the Orru v. Penetanguishene Mental Health Centre. He added that

not only does the Province have a legal obligation to provide sufficient space to meet its legal obligation for NCR persons like Mr. Pinet, but also the Province has a legal obligation to ensure that the Charter rights of NCR persons like Mr. Pinet and others are not violated. The Province cannot continue to plead a lack of bed space as the basis for continuing to breach the rights of NCR persons, like Mr. Pinet, who are in the total control of the state. It is not for the administrators or accountants to become the ultimate arbiters for the delivery of the most fundamental safeguards under Part XX.1 of the Criminal Code and sections 7 and 9 of the Canadian Charter of Rights and Freedoms. To do so would condemn NCR persons to a regime of discrimination and unaccountability. The Province is capable of doing better and should be taking active steps to remedy the injustice caused by the transfer delays due to lack of bed space. A proliferation of these types of applications to the courts is not the answer to solving these problems. Rather, the Province ought to take immediate remedial steps to resolve these issues."

Although these cases do not deal directly with assessment orders, they do highlight the Province's legal obligation to provide sufficient resources for mentally ill individuals.

\footnotetext{
${ }^{208}$ Pinet v. Penetanguishene Mental Health Centre, supra note 202 at para 46.

209 Ibid. at para 62.
} 
Both Justice Tomaso and Justice Glass condemn the Provincial Government for their failure to respond to the declaration made by Justice Desmarais in 2004 .

\section{The Need for Government Support}

On January 12, 2005, two months after the $R v$. Hussein and Dwornik Superior Court decision was handed down, the McGuinty Government made a public statement announcing $\$ 27.5$ million in funding directed toward community mental health agencies across the Province of Ontario. ${ }^{210}$ Although the Government funding has been welcomed by the organizations and those with an interest in mental health, the announcement did not address the specific problem mentally ill individuals are faced with in custody. The announcement outlined five distinct areas where the money would be invested: crisis response and outreach, short-term residential crisis support beds, court outreach services, intensive case management and supportive housing services. ${ }^{211}$ Rather than increasing the number of forensic beds the money was invested into programs designed to provide accused mentally ill persons with alternatives to jail. However, many of these programs take time to implement. This was highlighted in my interview with a member of the MOHLTC. In this interview the member discussed the lag time associated with implementing new policy and programs and commented that this delay is sometimes not acceptable to society. ${ }^{212}$ As we saw in the previous chapter this crisis facing the mental health and criminal justice systems is not a new one. Since the movement of deinstitutionalization there has been a push to increase resources within the community to serve mentally ill individuals. Furthermore, the Provincial government was made aware

\footnotetext{
${ }^{210}$ Online; Ministry of Health and Long Term Care <http://ogov.newswire.ca/ontario/GPOE/2005/01/12/c2146.html>. ${ }^{211}$ Ibid.

212 Interview of member from Ministry of Health and Long-term care, supra note at 163.
} 
of the specific problem regarding the lack of forensic beds for mentally ill individuals who needed an assessment more than ten years ago. Having knowledge of the time it takes to implement new initiatives the Ontario government should have been prompted to make significant changes to respond to the needs of the mentally ill before an order was issued by the Superior court in 2004.

Critics argue that "scattering 27.5 million annually across more than 130 agencies and institutions will do little to keep mental health patients out of the Province's jails". ${ }^{213}$ Furthermore, they argue that this announcement was actually part of an earlier $\$ 65$ million commitment to mental health that the McGuinty Liberals announced last June, $2004 .^{214}$ After the funding announcement was made the Government had four months to implement necessary changes to ensure resources were available and they were not acting in contravention to Justice Desmarais' court order.

\section{Mentally Ill Jailed in Contravention of Judge's Order}

When Justice Desmarais' six month deadline closed in May of 2005 no significant changes had been made to address the crisis facing accused mentally ill individuals awaiting an assessment. Newspaper headlines and media attention across the country revealed to the public that the problems were still alive and operating. "Crisis Looming as Mentally Ill Jailed in Disturbing Numbers", "Beds not Jail for Mentally Ill”, "Mentally Ill Jailed Despite Judges Order" and "Crisis Looms in Jails, Judge Warns" were just some of the captions grabbing Canada's attention. ${ }^{215}$ The landmark ruling that was supposed to

\footnotetext{
${ }^{213}$ Ontario Public Service Employees Union, supra note 165 at 1

${ }^{214}$ Ibid. at 1.

${ }^{215}$ S. Bailey, "Crisis looming as mentally ill jailed in disturbing numbers" The Western Star (23 November 2006) online: Proquest. <http://proquest.umi.com.>. J. Rupert, "Beds not Jail for Mentally Ill" The Ottawa Citizen (5 May 2005) online: Proquest. <http://proquest.umi.com.>. J. Rupert, "Mentally Ill Still Being Illegally Jailed"(3 November 2005). online: Proquest. <http://proquest.umi.com.>. "Crisis looms in jails, judge warns" Kamloops Daily (18 November, 2006). at B1 online: Proquest. <http://proquest.umi.com. $>$.
} 
be binding to all Ontario courts was breached when Shirley Michel, a woman suffering from schizophrenia was told on May 27, 2005 that she would be second on the waiting list for a bed at the Royal Ottawa Hospital. ${ }^{216}$ Ottawa criminal defence lawyer, Heather Perkins-McVey, who has an interest in representing people with mental illness, responded in an interview in 2005 to the Ottawa Citizen that the government's attempts to fix the situation have failed. She said "in the haste to move these people through the system quickly, the quality of reports have become poorer, and community supports have dwindled". 217 Ms. Perkins-McVey stated that government announcements of money to help and new programs to improve the lot of these people have simply failed. ${ }^{218}$ "I have not seen anything done to improve the system," she said. "There's a problem that needs to be fixed, and has needed to be fixed for some time. It's time to take this matter back to court".219

Bed Registry

Rather than announcing new assessment beds at the end of Justice Desmarais' six month deadline in May of 2005 , the Provincial government invested $\$ 30,000$ in the Ontario Forensic Mental Health Bed Registry. ${ }^{220}$ This system was an attempt to enhance and better organize crisis response systems across the Province. Mental Health Implementation Task forces across the region contended that a centralized housing registry would enable hospitals across the Province to effectively share administrative information for "streamline access and management" of severe mentally ill individuals. ${ }^{221}$

\footnotetext{
${ }^{216}$ J. Rupert, "Mentally Ill Jailed Despite Judges Order" The Ottawa Citizen. (27 May 2005). at P1.

217 Ibid. at 213

218 Ibid. at 213.

219 Ibid. at 213.

${ }^{220}$ Carrie Hayward Person in Charge, Centre for Addiction and Mental Health, Affidavit sworn August 31 , 2006. p 22. Court of Appeal for Ontario Her Majesty the Queen v. Romeo Rosete

${ }^{221}$ The Time has Come: Making it Happen. supra note at 146.
} 
In this way various stakeholders to the forensic mental health system can access information about available resources and bed use to assist the court with appropriate dispositions and orders. ${ }^{222}$ The idea is that if there were no forensic psychiatric assessment beds available in Ottawa, for example, and there was one available at Penetanguishene, that the accused could be sent to Penetanguishene to have the assessment conducted instead of waiting in custody. A fictitious online bed registry sample vacancy screen was provided to me from Mr. Higgins, senior program analyst, with the MOHLTC and can be seen below. It includes a listing of designated hospitals in Ontario providing dedicated forensic services, with the most recent bed availability data presented regarding each. For more information about any facility, including more detailed bed information and contact lists, court officers and Crown Attorney's who have access may click on the 'Details' button.

\section{Table 3.1 Bed Registry Vacancy Screen ${ }^{223}$}

Mental Health Centre Penetanguishene - Oak Ridge

Last Update: Thursday, January 18, 2007

Assessment Beds Available: 1

Details

Centre for Addiction and Mental Health - Toronto

Last Update: Thursday, January 18, 2007

Assessment Beds Available: 0

Details

Next Available: Friday, January 19, 2007

Thunder Bay Regional Health Sciences Centre

Last Update: Thursday, January 18, 2007

Assessment Beds Available: 2

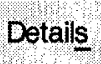

Royal Ottawa Health Care Group - Ottawa

Last Update: Thursday, January 18, 2007

Assessment Beds Available: 0

Details

Next Available: Wednesday, January 24, 2007

St. Joseph's Health Care - St. Thomas

\footnotetext{
${ }^{222}$ Ontario Forensic Mental Health Bed Registry Ministry of Health and Long-term Care. Online: http://www.bedregistry.com/ 2006.

${ }^{223}$ C. Higgins, < Chris.Higgins@moh.gov.on.ca>. January 18, 2007. Bed Registry. [E-mail to Krista Lazette klazette@hotmail.com.] personal communication.
} 
Last Update: Wednesday, January 17, 2007

Assessment Beds Available: 0

Next Available: Wednesday, January 31, 2007

Whitby Mental Health Centre

Last Update: Thursday, January 18, 2007

Assessment Beds Available: 0

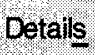

Next Available: Wednesday, January 31, 2007

Northeast Mental Health Centre - North Bay Campus

Last Update: Thursday, January 18, 2007

Assessment Beds Available: 0

Next Available: Friday, February 02, 2007

- Providence Continuing Care Centre - Kingston

Last Update: Thursday, January 18, 2007

Assessment Beds Available: 0

Next Available: Friday, February 02, 2007

Royal Ottawa Health Care Group - Brockville

Last Update: Thursday, January 18, 2007 Assessment Beds Available: 0

Next Available: Friday, February 02, 2007

Mental Health Centre Penetanguishene - Regional forensic Services

Last Update: Thursday, January 18, 2007 Assessment Beds Available: 0

Next Available: Monday, February 05, 2007

Page rendered on: Thursday, January 18, 2007

Unfortunately, rather than resolving the crisis at the interface of the criminal justice and mental health systems, many argue that the bed registry has exacerbated the problem. Some of these problems were highlighted in my interview with one Ottawa criminal defence lawyer. Firstly, there is a problem created by distance. Because the mentally ill person is sent far away from her family, psychiatrists are unable to use collateral information provided by family members or friends to assist with their assessment. Furthermore, there is no effort made to access necessary records from hospitals, general practitioners, or other primary stakeholders from that individual's community. This lawyer also highlighted the difficulty created for the accused mentally ill individual to access counsel. Defence counsel argue that after the assessment has been completed the individual will be returned in-custody to Ottawa, with a brief report 
containing limited information, which does not speak to issues of community support. As a result, the Doctor may be required to come to court to testify. Attendance in court of an out of town Doctor requires time and often results in further delays. In this lawyer's experience it has not been uncommon for the Royal Ottawa Hospital to have to re-conduct the assessment and engage the services of local supports. When asked about whether they would utilize the bed registry despite these recognized problems the lawyer stated that "I am strongly opposed to the use of the bed registry and will not consent, under any circumstances to have any of my clients put on a bed registry. This individual went on to say that "It was a brief attempt [by the Ontario Government] to get around the issue raised by Hussein and Dwornik". ${ }^{224}$ In my interview with Dr. Ward, she added that "we are trying to avoid the use of the bed registry here in Ottawa as it serves to create more problems" rather than resolve them. ${ }^{225}$

\section{Conclusion}

Although no real changes appeared to transpire at the end of the six month deadline issued by Justice Desmarais, his decision heightened awareness of the problem for all stakeholders involved with accused mentally ill individuals. Although the Ontario government's response to this issue shows a promising start to collaboration between the criminal justice and mental health systems, much more needs to be done. The conditions of detention centres and the impacts of incarceration on the mentally ill allow us to recognize the magnitude of this problem. It is important to recognize the vulnerability of accused mentally ill individuals and their specialized needs. The cases discussed in this chapter serve to reinforce the fact that accused mentally ill individuals have rights and it

\footnotetext{
${ }^{224}$ Interview of Ottawa criminal defence lawyer. supra note at 161.

${ }^{225}$ Interview of Dr. Ward. supra note at 159.
} 
is imperative that the courts continue to hold people accountable for their treatment. When the rights of mentally ill individuals are being infringed upon hearings should be held and evidence brought forward to correct these wrongs. Although Habeas corpus applications raise a number of ethical concerns I believe it is important for defence counsel to continue to place pressure on the Ontario government to implement necessary funding and resources. 


\section{Chapter 4: Moving Forward: Difficult Decisions Regarding Mentally Ill Offenders}

\section{Introduction}

It has been over three years now since the decision of Justice Desmarais was handed down and despite his order directing the provincial government to make changes by May 2005, accused mentally ill continue to be detained in jail in violation of their Charter rights. As a direct result of the Ontario government's failure to remedy the plight of the mentally ill, one Ottawa lawyer has filed a proposed class action lawsuit with the Superior Court of Ontario to obtain damages for the unconstitutional detention of these individuals. ${ }^{226}$ Given the growing number of class members listed under the claim this proceeding, if successful, would have significant monetary ramifications for the government. However, since this suit was filed on January 16, 2006, an appeal has been filed by the Ontario Government in the Court of Appeal under $R v$. Rosete, submitting that "the assessment provisions of the Criminal Code were written so as to allow for a reasonable period of time in which the accused can be lawfully detained in a detention centre pending transfer to a hospital for assessment". ${ }^{227}$ The outcome of this decision could overturn the order made in $R v$. Hussein and Dwornik, and could potentially sideswipe the class action suit in Phaneuf v. Her Majesty the Queen in Right of Ontario.

Despite the allegations made in recent court decisions against the provincial government, as illustrated in chapter three, the government continues to highlight its commitment to implementing new funding and program initiatives which it indicates will promote the timely delivery of forensic mental health services. However, the recommendations of these reports and advisory committees are not responding to a new

\footnotetext{
${ }^{226}$ Obagi, supra note 187 at 7.

${ }^{227}$ Her Majesty the Queen v. Rosete and Centre for Addiction and Mental Health. 2006. Appellant's Factum at para. 38.
} 
phenomenon. As we have seen in Chapter two, despite widely disparate ideological viewpoints, all political parties that have formed governments in Ontario since 1983 have had remarkable unanimity about the future of mental health care in Ontario. ${ }^{228}$ They continue to highlight the vitality of appropriate and accessible mental health services and the importance of community resources. I agree that in order to relieve the pressure on the forensic system we must utilize community mental health resources so that forensic assessments can be conducted on an out of custody basis. However, the fact that mentally ill individuals continue to be detained in custody awaiting a court ordered psychiatric assessment, rather than in the community, as the Criminal Code presumes, is evidence that adequate community supports have not yet been provided for mentally ill offenders.

Although Garland's work focused on punishment, his analysis of penal practices is useful in understanding the problems outlined here. The state continues to highlight its commitment to accused mentally ill and maintains that increased funding and the expansion of community services will alleviate the pressures on the mental health system resulting from the divestment of psychiatric hospitals. ${ }^{229}$ Similarly, to the extent that the state seemed to be loosing its "war against crime" this was seen "as a problem of resources and knowledge, or of methods and implementation, and plans were laid for further research, increased funding" and the expansion of services. ${ }^{230}$ Here, as with the official discourses discussing the "war against crime" in the 1960s, the state casts no doubt on its capacity to deal with the problem. Garland would caution that we ought to recognize the "limits of the sovereign state" on the ways in which we imagine and offer

\footnotetext{
${ }^{228}$ CMHA, supra note at 109.

${ }^{229}$ Making it Happen, supra note at 146.

${ }^{230}$ Garland, supra note 88 at 453.
} 
to provide services for accused mentally ill. Although recent funding announcements are welcome, there have been no real changes to provide services in the Ottawa community. Despite the proceedings in the Ontario Court of Appeal, it is imperative that the provincial government recognize these limitations and continue to move forward to provide mentally ill offenders with an integrated system of care at the interface of the mental health and criminal justice systems.

\section{Phaneuf v. Her Majesty the Queen in Right of Ontario}

As a result of the government's continued failure to implement necessary changes for mentally ill persons awaiting an assessment, certification for a class action lawsuit has been commenced in Phaneuf v. Her Majesty the Queen in Right of Ontario. This action includes all persons in Ontario who are, were or will be detained in a detention centre pending transfer to a hospital for an in-custody psychiatric assessment pursuant to section 672.11 of the Criminal Code since November 10, 2004. ${ }^{231}$ The claim alleges that the detention of accused individuals awaiting a psychiatric assessment violates their Charter rights and that the Ontario government ignored a Court order which required it to "cease and desist" from placing these persons in custody while awaiting a bed. ${ }^{232}$ The plaintiff in this matter, Sylvie Phaneuf, was charged with criminal harassment on November 1 , 2005 and subsequently ordered for a psychiatric assessment pursuant to section 672.11 of the Criminal Code on November 2. Counsel for the prosecution advised Ms. Phaneuf's counsel that there were three individuals before her on the list waiting for an assessment. As a result, Ms. Phaneuf was placed at the Ottawa Carleton Detention Centre and continued to be detained there up until January 16,2006 , the date the class action suit was

\footnotetext{
${ }^{231}$ Statement of Claim Phaneufv. Her Majesty the Queen in Right of Ontario Janaury 16, 2006 at 3 232 Ibid. at 3.
} 
filed with the Ontario Superior Court. Counsel alleges that at the detention facility Ms. Phaneuf was subject to verbal and physical abuse by other residents and detained under maximum security restrictions "where over-crowding and violence is common, further endangering her physical and psychological safety".233

An online form was generated for victims of section 672.11 to identify themselves as potential class members in the legal proceedings. ${ }^{234}$ The Plaintiff, Sylvie Phaneuf, on her own behalf and on behalf of the other class members, claims general damages in the amount of $\$ 25,000,000.00$, special damages in the amount of $\$ 1,000,000.00$, and punitive damages in the amount of $\$ 25,000,000.00$, or such other amount as may be approved by the Court, "as well as the costs of the action on a substantial indemnity basis". ${ }^{235}$ In an affidavit sworn by Sawsan Khowessah, a Senior Social Worker and Special Needs Consultant with the Ministry of Community Safety and Correctional Services (MCSCS), an estimate number of potential class members was provided. The MCSCS is able to identify persons subject to assessment orders under section 672.11 of the Criminal Code using the Offender Tracking Information System (OTIS). During the period from May 10, 2005, when Justice Desmarais' order came into effect, until October 31, 2006 there were approximately 1,576 assessment orders made province wide that resulted in the detention of the accused person in an Ontario provincial correctional facility. ${ }^{236}$ Ms. Khowessah states that this figure must be regarded as an estimate rather than a certain

\footnotetext{
${ }^{233}$ Phaneuf v. Her Majesty the Queen in Right of Ontario supra note 229 at 6.

${ }^{234} \mathrm{~J}$. Obagi, "Victims of Section 672.11" online: Cooligan \& Ryan $<\mathrm{http}: / /$ www.cooliganryan.com/victims.cfm>.

${ }^{235}$ Phaneuf v. Her Majesty the Queen in Right of Ontario supra note 229 at 3.

${ }^{236}$ Affidavit of Sawsan Khowessah, Sylvie Phaneuf v. Her Majesty the Queen in Right of Ontario. Sworn

December 8, 2006. at para. 4(b).
} 
figure, however, this number makes us aware of the substantial amount of individuals being detained in contravention of their Charter rights.

Although the OTIS is unable to provide an accurate representation of the amount of time a given individual has waited for the assessment, I was able to obtain statistics from the Ottawa Court Police Liasion Office regarding the wait times for individuals in Ottawa subject to assessment orders. The information provided included the name of the individual, the date that an assessment was ordered, the date a bed became available and the total number of adjournments made prior to the bed becoming available. I received complete information for 53 of the 56 individuals who were ordered for an assessment pursuant to section 672.11 of the Criminal Code from January to September 2006. The information set out below in Chart 4.1 reveals that 27 of the 53 individuals waited 15 days or more in custody for a bed to become available in violation of their Charter rights. 


\section{Chart 4.1 Duration of Time Spent in Custody Awaiting a Psychiatric Assessment ${ }^{237}$}

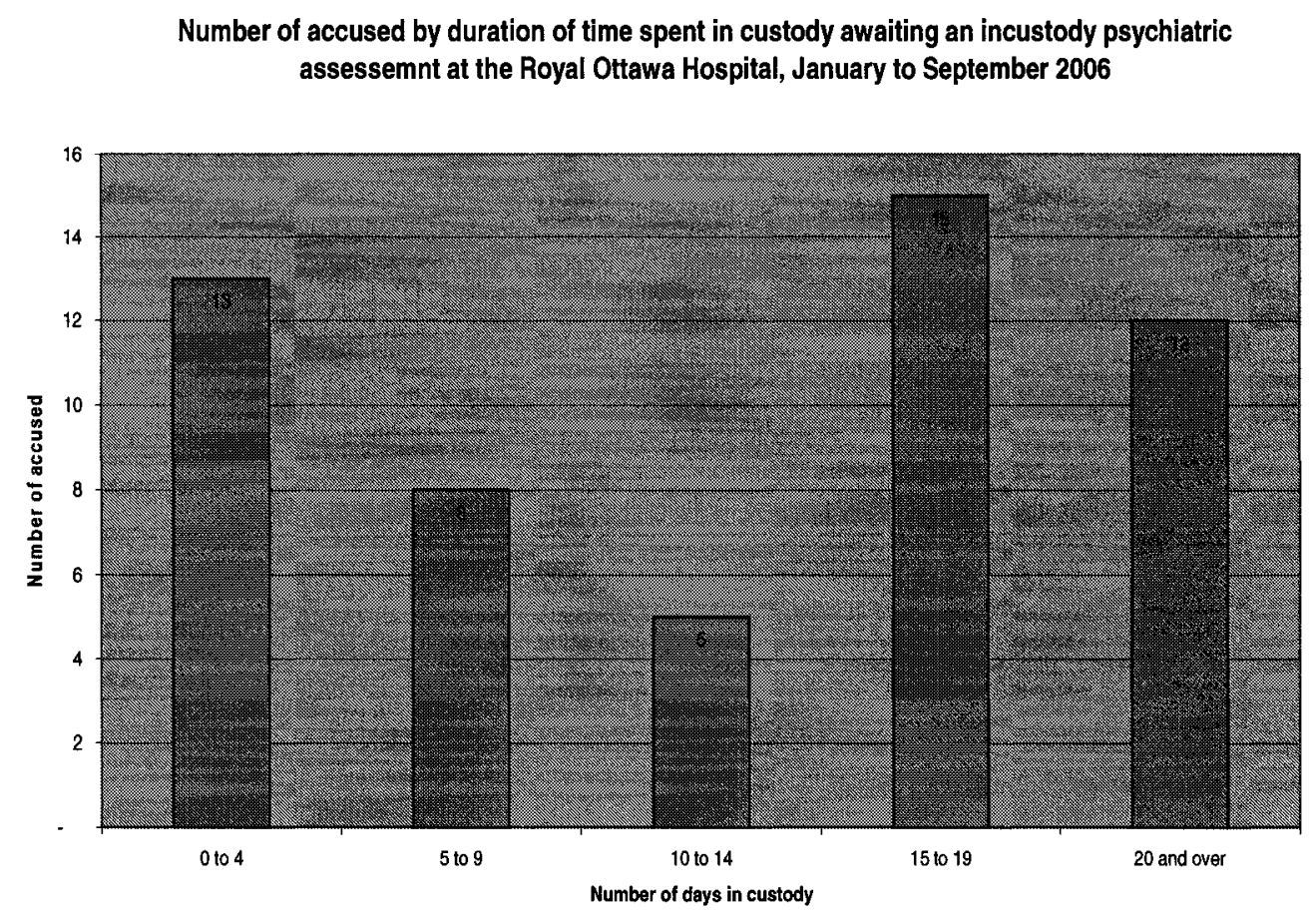

Source: Sandy Mitchell. Ottawa Police Court Liason Office, January to September 2006

Total Number of Accused $=53$

The statistics also revealed that one individual waited at the Ottawa Carleton Detention Centre for 42 days before a bed became available.

The Affidavit material filed by Carrie Hayward, Director of the Mental Health and Addiction Branch of the Ministry of Health and Long Term Care, presents information that suggests fitness clinics could be utilized to reduce the costs and waiting times associated with in-patient fitness assessments. Fitness clinics were established so that in-custody fitness assessments could be conducted by psychiatrists at the detention centre where the individual is in custody. To support this information Ms. Hayward relies on advice from the Forensic Director's Group, which is comprised of both Clinical and Administrative Directors, as well as two MOHLTC Regional office representatives

${ }^{237}$ S. Mitchell, Ottawa Court Police Liasion Office. Ottawa, Ontario, January to September 2006. 
and one senior program analyst from the mental health unit, and results from a pilot project. $^{238}$ This pilot project, conducted in 1999 at the Hamilton-Wentworth Detention Centre fitness clinic by Dr. Chaimowitz, was designed to determine whether these clinics could be utilized to reduce costs and wait times associated with in-custody psychiatric assessments. The research presented by Dr. Chaimowitz found that the interview process would require between 10 and 60 minutes with the accused and a further hour and a half for preparation time including collections of medical reports review of the charges etc.. ${ }^{239}$ He stated that the results of the assessment are usually provided verbally after the assessment and the production of a written report could be completed within 24 to 48 hours. $^{240}$ His findings also revealed that the majority $(74 \%)$ of individuals referred for the assessment were found fit to stand trial. ${ }^{241}$ When corresponding with Senior Program Analyst with the MOHLTC, Christopher Higgins, he stated that

this indicates that courts have difficulty discerning who needs such assessments. As a consequence, we know that $75 \%$ of people found on wait lists for fitness assessments are fit individuals. Even a modest decrease in false positives (sent for fitness assessments but were fit) by the courts would reduce the wait times considerably. At this point I would estimate that a $25 \%$ reduction in false positives would, virtually eliminate significant wait times. $^{242}$

When considering these statistics one must keep in mind that although the provisions of the Criminal Code pertaining to assessment orders do not require the opinion of medical professionals in order to support the assessment order, studies have revealed that independent decisions made between the courts and mental health professionals are often

\footnotetext{
${ }^{238}$ Hayward, supra note 218 at para. 50

${ }^{239}$ G. Chaimowitz, "Cost Savings Associated with Fitness To Stand Trail Assessments in Detention Centres: A Pilot Program” (1999) 44 Can J Psychiatry 808 at 809

${ }^{240}$ Ibid. at 809.

${ }^{241}$ Chaimowitz, supra note 237 at 809 .

${ }^{242}$ Higgins, supra note at 221.
} 
in agreement. In fact, one study revealed that the agreement rate between mental health professionals' opinions and court determinations of an assessment to assess fitness to stand trial is typically above $90 \% .^{243}$ So, although the court is solely responsible for making the assessment order, these results suggest that even with a medical expert's opinion an assessment would still be ordered.

These findings raise a number of interesting issues. First, although $74 \%$ of these individuals have been found fit to stand trial, nearly half of the sample population were still suffering from some form of mental illness at the time of the assessment. Dr. Chaimowitz's study revealed that $49 \%$ of the 53 individuals on the assessment order were suffering from various psychiatric diagnoses including: schizophrenia, schizo-affective disorder, major mental disorder, delusional disorder, psychosis, bipolar affective disorder, and primary diagnosis of personality disorder. ${ }^{244}$ Although some of these individuals may have been found fit to stand trial, because of the low threshold for fitness, many of them are clearly still suffering from a mental illness. ${ }^{245}$ As discussed in Chapter 2 Dr. Ward cited the above reasons for favouring the approach of keeping individuals for the duration of the assessment. Although costs and wait times may be reduced, the fitness clinic does not provide the opportunity for efforts to be made to connect the individual with community resources and housing to generate an aftercare plan. Currently, there does not appear to be empirical evidence on whether individuals who have an aftercare plan available upon the completion of an assessment order and those who do not, however, it would be interesting to see whether individuals who have an aftercare plan

${ }^{243}$ P. Zapf et. al. "Have the Courts Abdicated Their Responsibility for Determination of Competency to Stand Trial to Clinicians?" (2004) 4 Journal of Forensic Psychology Practice 27 at 27.

${ }^{244}$ Chaimowitz, supra note 237 at 809 .

${ }^{245}$ An individual can be considered to be fit if they are able to communicate what the roles of the Judge, defence counsel, and crown attorney are. 
are less likely to re-offend and/or deteriorate. Evidence does suggest that when individuals are released from hospital into the community without the support of a mental health staff person they are more likely to become homeless, arrested and jailed. ${ }^{246}$

Roesch and Golding argue that the large percentage of individuals referred for fitness assessments who are found fit are at least partly accounted for by "attempts of the criminal justice system to "backdoor" individuals into the treatment system". 247 This possible trend became evident when speaking with Dr. Ward. She indicated that the Ottawa Civic Hospital has 40 psychiatric beds and within the first twelve days of October, 2006 there were 42 admissions. $^{248}$ As a result, immense pressure is placed on the mental health system and raises concerns as to what happens to those who are unable to access these services. Dr. Ward stated, "I routinely see people who were turned away or charged by police because the emergency room wouldn't admit them". ${ }^{249}$ What are the expectations of the services the criminal justice system can provide? The criminal justice system is being used as a golden key to access mental health services and treatment. Although I do believe that these expectations of the criminal justice system are much too high, the mental health system should be responsible for individuals in custody identified as having a mental illness. Since evidence suggests that a mental illness may still be operating even though an individual has been found fit after an assessment, efforts should be made to connect these individuals with appropriate mental health community services upon their release. It is important for the mental health system and legal system to work

\footnotetext{
${ }^{246}$ Zapf, "An Examination of the Relationship of Homelessness to Mental Disorder, Criminal Behaviour, and Health Care in a Pretrial Jail Population" (1996) 41 Can J Psychiatry 435 at 439.

${ }^{247}$ R. Roesch, J.R.P. Ogloff, \& D. Eaves, "Mental Health Research in the Criminal Justice System" (1995)

18 International Journal of Law and Psychiatry 1 at 6.

${ }^{248}$ Interview with Dr. Ward. supra note at 159.

249 Ibid.
} 
together to reduce the revolving door cycle of admissions to both jail and mental health facilities.

In a paper presented at the Mental Health Conference in Toronto in 2006 Joseph Obagi, counsel for Ms. Phaneuf, wrote that

this class action suit is intended to give a voice to the mentally ill who are in the total control of the state. These individuals are among the most defenseless groups in our society and require a greater degree of protection by government. It is in this context that the conduct of the government must be judged. ${ }^{250}$

The proposed class action suit is the latest move to prompt the government to respond to the problem which is plaguing Ontario's criminal justice system. The outcome of this class action suit will raise many issues with regards to the liability of hospitals and corrections, however, it will be some time before this decision will materialize. A date had been set to commence certification of the class action lawsuit on January 16, 2007, but an adjournment was requested by both parties and a new date for the motion of certification has been set on April 30, 2007.

\section{R v. Rosete: Can Detention be Justified?}

Since the above motion for certification of the class action lawsuit was commenced, the case of $R v$. Rosete has been appealed to the Ontario Court of Appeal. The Government argues that they are entitled to hold individuals in custody while awaiting a psychiatric assessment. Mr. Rosete was charged with various offences arising out of allegations of an incident with his spouse. After some concern regarding his mental condition Justice Schneider ordered for him to be delivered to CAMH no later than the $11^{\text {th }}$ day of April 2006 to undergo an assessment pursuant to section 672.11 (a)

${ }^{250}$ Phaneuf v. Her Majesty the Queen in Right of Ontario, supra note 229 at 10. 
of the Criminal Code of Canada. ${ }^{251}$ However, Mr. Rosete was not delivered to the hospital, but rather remained incarcerated in a Toronto jail.

In response to this situation defence counsel brought an application for a writ of a habeas corpus to the Superior Court of Ontario. The parties appeared before Justice Nordheimer on April 13, 2006 where counsel sought, among other things, Mr. Rosete's release from custody. ${ }^{252}$ Justice Nordheimer stated:

THE COURT: Well it's not clear that there is an unlawful detention, Mr. Hynes. There's nothing in the record before me that suggests that your client is unlawfully detained. It's that he hasn't been subjected to an assessment.

THE COURT: And that's a fair concern, but it's a concern that can be addressed before Justice Schneider. It's not - this is not a situation, on the evidence before me, where it's a situation whether Mr. Rosetti [sic] should be in jail or not in jail. It's a situation where Mr. Rosetti [sic] is in jail because he's charged with serious criminal offences, and the issue is, as I understand it, whether he's fit to stand trial on those offences, and whether, instead of being in a detention facility, he ought to be in a secure hospital facility. ${ }^{253}$

Justice Nordheimer did not make a ruling on the habeas corpus application, but rather returned the matter before Justice Schneider in the Ontario Court of Justice without any clear direction as to how to proceed.

As a result, when Mr. Rosete subsequently appeared before Justice Schneider on April 20, 2006, his honour determined that Justice Nordheimer had delegated him the authority to hear the application pursuant to section 775 of the Criminal Code. ${ }^{254}$ Justice Schneider stated that

while the Ontario Court of Justice has no inherent jurisdiction to hear applications for extraordinary remedies at first instance, the

\footnotetext{
${ }^{251} \underline{\text { R v. Rosete, }}$ [2006] O.J. No. 1608

252 Her Majesty the Queen v. Romeo Rosete and Centre for Addiction and Mental Health. The Court of Appeal for Ontario Appellant's Factum.

${ }^{253}$ R v. Rosete, supra note 249 at p. 34 line 10.

254 Ibid. at para 1 .
} 
Order made by the Superior Court pursuant to the provisions of section 775 bestows upon this court the ability to "take any proceedings, hear such evidence or do any other thing that, in the opinion of the court or judge, will best further the ends of justice. $^{255}$

First, before determining the issue, Justice Schneider ordered that the accused be assessed in court. A fitness hearing was conducted and Mr. Rosete was subsequently found unfit that same day. ${ }^{256}$

Justice Schneider then addressed the habeas corpus application and stated that "the matter of mentally disordered accused waiting inordinate lengths of time prior to being admitted to hospital for assessment or treatment...is unfortunately a problem that has plagued the courts of this province for a number of years". ${ }^{257}$ In support of this conclusion the judge referred to the judicial decisions of $R v$. Hussein and Dwornik, $R v$. Orru, and $R v$. Pinet, which all maintain that this situation runs afoul of various Charter guarantees. $^{258}$ Justice Schneider also heard testimony from Dr. Barbaree, Clinical Director of the Law and Mental Health Program at CAMH, who indicated that, "rather than the ideal $80 \%$, his facility is typically running at $103 \%-105 \%$ of capacity and, as a result, has incurred labour complaints. ${ }^{259}$ Clearly, the limited forensic resources available at $\mathrm{CAMH}$ are operating above capacity to assist accused mentally ill individuals in accessing services.

Of particular importance is Justice Schneider's interpretation of assessment orders.

In Mr. Rosete's circumstances the court has the authority to detain him for the purposes of his psychiatric assessment; and for the

\footnotetext{
${ }^{255} \mathrm{R}$ v. Rosete supra note 249 at para 2.

${ }^{256}$ Her Majesty the Queen v. Romeo Rosete and Centre for Addiction and Mental Health. The Court of Appeal for Ontario Appellant's Factum at para. 5.

${ }^{257}$ R v. Rosete supra note 249 at para. 4.

258 Ibid. at para. 4.

${ }^{259}$ Ibid. at para. 5.
} 
purpose the court may send the accused to a hospital, as defined in section 672.1. There is no authority to incarcerate the accused in jail. Nowhere in Part XX.1 of the Code is the court given the power to place an accused in jail at this juncture. He is not serving a sentence, he is presumed to be innocent, he has not even been arraigned...The only purpose for interfering with $\mathrm{Mr}$. Rosete's liberty is for the purpose of effecting his assessment to determine his fitness to stand trial...To my mind all accused should be delivered to hospital on a forthwith basis with no 'stopovers' at a jail along the way. ${ }^{260}$

Justice Schneider also concluded that the MOHLTC must be accountable for the lack of adequate resources available for accused individuals awaiting an assessment. ${ }^{261} \mathrm{He}$ stated that "the delay in delivering Mr. Rosete to hospital as Ordered by this court was "entirely and exclusively" the product of an insufficient number of beds at CAMH". ${ }^{262}$ Furthermore, his Honour noted that the bed registry, outlined in Chapter three, is fundamentally flawed and not a function the court is competent to perform. ${ }^{263}$ For all of these reasons Justice Schneider found that the accused's detention at the Toronto Jail was unlawful and infringed his rights guaranteed by section 7 and 9 of the Charter. ${ }^{264}$ Ultimately, Schneider J. granted the following declaration:

There will be a declaratory order pursuant to the authority of section 775 of the Criminal Code that to detain Mr. Rosete in a jail while he is the subject of an Assessment Order pursuant to the provisions of section $672.11(\mathrm{a})$ is unlawful. ${ }^{265}$

\section{Issues on the Appeal}

The Crown appealed the judgment issued on the return of the writ of habeas corpus of Justice Schneider in accordance with section 784(5) of the Criminal Code on the grounds

\footnotetext{
${ }^{260} \underline{R}$ v. Rosete, supra note 249 at para. 9.

261 Ibid. at para 13.

262 Ibid. at para. 11.

263 Ibid. at para. 13.

${ }^{264}$ Her Majesty the Queen v. Romeo Rosete and Centre for Addiction and Mental Health supra note 254 at para. 25 .

${ }^{265} \underline{\mathrm{R}} \mathrm{v}$. Rosete, supra note 249 at para 16.
} 
that his Honour acted without jurisdiction in issuing a judgment on the writ and that his judgment must be quashed. ${ }^{266}$ The Crown alleges that Justice Nordheimer "clearly appreciated that the Superior Court was the only court with jurisdiction to hear an application for habeas corpus". ${ }^{267}$ The Crown further submits that the lack of clear direction provided from Justice Nordheimer "does not allow a provincial court judge to arrogate to himself the authority to decide issues for which he has no jurisdiction, including determining whether Mr. Rosete was lawfully detained". ${ }^{268}$

Should the Court of Appeal quash Justice Schneider's judgment, the Crown requests a further ruling on whether Justice Schneider erred in his interpretation of the assessment order provisions of the Criminal Code. The Appellant argues that given the finite number of hospital beds and the competing demands for their use, "the assessment provisions of the Criminal Code were written so as to allow for a reasonable period of time in which an accused can be lawfully detained in a detention centre pending transfer to a hospital for assessment" ${ }^{269}$ The Crown submits instead that the court should have access to the necessary information which would enable them to determine where and when a bed will be available to issue an appropriate order. The Appellant argues that both section $672.13(1)(\mathrm{b})$ of the Code and the assessment forms (Form 48, 48.1) ${ }^{270}$ anticipate that an accused subject to an in-custody assessment will be detained at a

\footnotetext{
${ }^{266}$ Her Majesty the Queen v. Romeo Rosete and Centre for Addiction and Mental Health supra note 254 at para. 27.

${ }^{267}$ Ibid. at para. 29.

${ }^{268}$ Ibid. at para. 34.

269 Ibid. at para. 38.

270 Both forms are attached and listed as Appendices E and F.
} 
facility other than where the assessment is to occur by providing the court with the opportunity to specify a location. ${ }^{271}$

\section{Funding Initiatives}

On August 31, 2006 Carrie Hayward, Speaker in Charge for the MOHLTC, filed an Affidavit with the Ontario Court of Appeal describing the relationship of the MOHLTC with other stakeholders of the mental health and justice system in providing various services with respect to assessments. ${ }^{272}$ Of particular interest is her discussion of new funding initiatives since the decision of $R v$. Hussein and Dwornik. The first of which Ms. Hayward highlights is the December 2002 report "Assessment, Treatment and Community Reintegration of the Mentally Ill Offender". ${ }^{273}$ This report, which has not been formally adopted by the Government, echoes the recommendations of those made in the province of Ontario over the past 20 years with respect to the care and treatment of accused mentally ill which were outlined in Chapter two. The report reiterates that there is a vital need to develop accessible community supports and housing for accused mentally ill. I strongly agree with this report, as well as the previous recommendations to implement these services as a means to alleviate the pressures on the forensic system, however, this need has been clearly documented in the past. Mentally ill individuals who are charged with relatively minor offences are frequently detained for assessments despite the presumption in the Criminal Code for them to be dealt with on an out of custody basis. Without available community mental health services for these types of offenders

\footnotetext{
${ }^{271}$ Her Majesty the Queen $v$. Romeo Rosete and Centre for Addiction and Mental Health supra note 254 at para. 42.

${ }^{272}$ Hayward, supra note 218 at para. 3.

273 "Assessment, Treatment and Community Reintegration of the Mentally Ill Offender" Forensic Mental Health Services Advisory Panel December 2002 online at: < http://www.health.gov.on.ca/english/providers/pub/mhitf/forensic_panel/final_report.pdf $>$.
} 
Judges are left with no alternative but to order in-custody assessments. More than two years have passed since the Ontario Government announced funding for short-term crisis beds, however, one Ottawa Criminal Defence lawyer, indicated that to date no transitional or interim support beds have been implemented for forensic mental health patients. ${ }^{274}$

On April 27, 2006 the Minister of Health and Long Term Care, George Smitherman, announced $\$ 20$ million for the expansion of hospital and community services. ${ }^{275}$ The Minister indicated that this new funding would include 75 new forensic hospital beds and 30 additional forensic case managers. ${ }^{276}$ Ms. Hayward indicated in her affidavit material that funding was available for up to 15 of these new beds to open in January 2007 in Ottawa. ${ }^{277}$ However, Dr. Ward indicated on January 21, 2007 that the beds were not yet in operation and interviews for additional forensic staff had not been completed. $^{278}$ The opening of the new ROMHC was held on October 30, 2006 and patients were transferred into the hospital later that same week. In two of the interviews I conducted with key informants both were unable to comment with regards to the number of beds which had been constructed at the ROMHC in the secure forensic unit. Although I have not received a definitive answer, it appears that given that the funding has been approved and the new hospital has been built, up to 15 beds have remained vacant within for the past four months.

\footnotetext{
${ }^{274}$ Interview with Ottawa Criminal Defence Lawyer, supra note at 161.

275 "McGuinty Government Improving Access to Forensic Mental Health Services" April 27, 2006. online at: <www.health.gov.on.ca>

${ }_{276}$ Ibid. at 30.

${ }^{277}$ Hayward, supra note at 218.

${ }^{278}$ Follow-up Interview with Dr. Ward, January 21, 2007.
} 


\section{Conclusion}

It is clear that the case of $R v$. Hussein and Dwornik has generated a lot of attention within the mental health and criminal justice systems. Since Justice Desmarais' decision the Ontario Government has reiterated their commitment to assisting accused mentally ill individuals and maintains that they will continue to implement new funding initiatives to promote the timely delivery of forensic mental health services. Unfortunately, the lack of available community mental health services and housing is not a new phenomenon. This case is simply the first legal decision directing the Government to respond to a specific problem facing accused individuals waiting in-custody for a psychiatric assessment. The growing number of class members identified in Phaneuf $v$. Her Majesty the Queen in Right of Ontario serves to remind us of the importance of responding to the needs of this specialized group of offenders. Although the judgment of the Ontario Court of Appeal in Her Majesty the Queen v. Romeo Rosete and Person in Charge, Centre for Addiction and Mental Health may have significant implications for accused mentally ill individuals awaiting an assessment, the Provincial government should continue moving forward to address this crisis.

\section{Conclusion}

As of March 28, 2007 there were three accused individuals detained at the Ottawa Carleton Detention Centre who were waiting for an assessment of their criminal responsibility or fitness. As I write this conclusion I think about the decisions facing the Ontario Court of Appeal in Her Majesty the Queen v. Rosete and the Centre for Addiction and Mental Health. I am reminded of Justice Tomaso's claim that the mindset of the MOH suggests that it is only prepared to deal with "these types of cases on a "squeaky 
wheel" or "piece meal" basis...". ${ }^{279}$ The continued violation of the Charter rights of mentally ill individuals awaiting a psychiatric assessment is just one of many problems that the interface of the mental health and criminal justice systems are presented with when responding to this specialized group of offenders.

Throughout this paper I have attempted to locate the unconstitutional detention of mentally ill individuals within broader political, legal and social contexts. In this research project we have seen that the institutionalization, and later deinstitutionalization of mentally ill individuals runs parallel to other movements in health and correctional practices. When thinking about the history of the mentally ill one must consider the diverse interests of various stakeholders in the mental health and justice systems, including those of academics, civil libertarians, pharmaceutical companies, physicians, families, and government. Each of these groups are governed by a different set of practices which are often conflicting and driven by personal gain. As a result of these diverse interests in mental health not working in collaboration with one another, we have significantly impeded our ability to provide these individuals with the support and services they require.

A review of the mental health system's response to individuals suffering from mental health problems reveals a cyclical pattern of ineffective treatment and care for these individuals. The movement of the mentally ill into the community was possibly one of the most complex policy shifts in the history of Canada. Although this movement was not ill-intended, the failure to implement a comprehensive policy framework hindered the support of community based housing and services to assist the mentally ill with this transition. Unfortunately, since this shift the population of homeless mentally

${ }^{279}$ Pinet v. Penetanguishene Mental Health Centre, supra note 202 at para 46. 
ill individuals has increased and they are becoming a significant group of offenders within the criminal justice system. While efforts are being made to divert mentally ill individuals from the justice system, many are ordered for an assessment of their fitness or criminal responsibility pursuant to section 672.11 of the Criminal Code of Canada. Due to a shortage of beds at the ROMHC and lack of available community resources a practice has evolved whereby individuals ordered for an assessment are detained in custody until the time of their assessment.

Providing a solution to this problem requires more than simply increasing funding to implement new forensic beds. There is a need to evaluate the established practices and policies in place for dealing with accused mentally ill offenders. Furthermore, there is a need to re-evaluate the expectations of the criminal justice system to respond to specialized offenders. This paper has demonstrated that there is often a large discrepancy between rhetoric and practice. One must be cognizant of the backdrop of social and political movements impacting the decisions of members within the mental health and justice systems. Methods of accountability are required to ensure that all stakeholders of these systems are working in collaboration with one another to provide the mentally ill with an integrated system of care. It is my hope that it will be evident in the decision of the Court of Appeal that some of the issues raised in this paper have been addressed and work to resolve the problems facing accused mentally ill. 


\section{Bibliography}

Acorn, S. "Mental and physical health of homeless persons who use emergency shelters in Canada" (1993) 44 Hospital and Community Psychiatry 854.

Affidavit of Sawsan Khowessah, Sylvie Phaneuf v. Her Majesty the Queen in Right of Ontario. Sworn December 8, 2006. at para. 4(b).

Arboleda-Florez, J. "The Effects of Changes in the Law Concerning Mentally Disordered Offenders: The Alberta Experience with Bill C-30" (1995) 40 Canadian Journal of Psychiatry 225.

Bachrach, L., P Goering, \& D. Wasylink, Eds. "Mental Health Care in Canada" 61 New Directions for Mental Health Services. (1994). 1.

Bachrach, L. "Deinstitutionalization: What Does it Really Mean?" Schizophrenia: Exploring the Spectrum of Psychosis. (1994) 21.

Bradford, J. "Mentally Disordered Offenders and the Law" Canadian Journal of Psychiatry. 40 Ottawa; Canada, June 1995. 223.

Bailey, S. "Crisis looming as mentally ill jailed in disturbing numbers" The Western Star (23 November 2006) online: Proquest. <http://proquest.umi.com.>.

Bryant, T. "The Current State of Housing in Canada as a Social Determinant of Health" Policy Options. (2003). 52.

Canadian Association of Independent Living Centres. (1993) Independent Living: An agenda for the '90s. Ottawa: Canadian Association of Independent Living Centres.

Canadian Charter of Rights and Freedoms. Department of Justice Canada http://laws.justice.gc.ca/en/charter/index.html online: December 14, 2006

Chaimowitz, G. "Cost Savings Associated with Fitness To Stand Trail Assessments in Detention Centres: A Pilot Program” (1999) 44 Can J Psychiatry 808.

"Chronology of Reports, Recommendations and Plans for Mental Health Care Reform" online: Canadian Mental Health Association < http://www.ontario.cmha.ca $>$.

Cousins, M. \& Athar Hussain. Michel Foucault (London: MacMillan Education Ltd., 1984).

"Crisis looms in jails, judge warns" Kamloops Daily (18 November, 2006). at B1 online: Proquest. <http://proquest.umi.com. $>$.

Cullen, F. "The Twelve People who Saved Rehabilitation: How the Science of Criminology Made a Difference" (2005) 43 Journal of Criminology Volume 1. 
"Mental Illness Glossary" online: Canadian Mental Health Association $<$ http://www.cmha.ca/bins/content_page.asp?cid=3-424\&lang=1>.

Davis, S. "Assessing the criminalization of the Mentally IIl in Canada." Canadian Journal of Psychiatry. 8. (1992). 532.

Davis, S. "Changes to the Criminal Code Provisions for Mentally Disordered Offenders and their Implications for Canadian Psychiatry" (1993) 38 Canadian Journal of Psychiatry 122.

Davis, S. Community Mental Health in Canada: Theory Policy and Practice. (Vancouver: UBC Press; 2006).

Davies, G, S. Lloyd-Bostock, \& M. McMurran, Eds. Psychology, Law and Criminal Justice. (New York: Walter de Gruyter; 1996).

Eberle, M. "The Relationship between Homelessness and the Health, Social Services and Criminal Justice System: A Review of the Literature" (2001) 1 Homelessness: Causes and Effects. 1.

Ekstedt, J. and C, Griffiths, Corrections in Canada: Policy and Practice (Toronto: Butterworths publishing, 1988).

M. Feeley, and J. Simon, "The New Penology: Notes on the Emerging Strategy of Corrections and its Implications" (1992) 30 Criminology 449.

Foucault, M. Madness and Civilization: A History of Insanity in the Age of Reason. (New York: Pantheon Books, 1965).

Garland, D. The Culture of Control (Chicago; University of Chicago Press: 2001).

Garland, D. "The limits of the sovereign state: strategies of crime control in contemporary society" (1996) 36 British Journal of Criminology 445 at 446.

Goffman, E. Asylums (Chicago: Aldine Publishing Company, 1961).

Golden, A. Report of the Mayor's Homelessness Action Task Force: Taking Responsibility for the Homeless: An Action Plan for Toronto (Toronto: City of Toronto,1999).

Graham. R. "Building Community Support for People: A Plan for Mental Health in Ontario" (1988) Ontario.

Gray, J., M. Shone \& P. Liddle, Canadian Mental Health law and Policy. (Toronto: Butterworths; 2000). 
http://www.ropeofsilicon.com/movies.php?id=1687 online: November 16, 2006.

Higgins, C. Ministry of Health and Long-term Care. January 18, 2007.

Hoge, M.A., "Defining Managed Care in Public Sector Psychiatry." (1994) 45 Hospital and Community Psychiatry 1085.

Horwitz, A. \& Scheid, T. ed. A Handbook for the Study of Mental Health. (London: Cambridge University Press, 1999).

Idziak v. Canada (Minister of Justice) (1989) 53 C.C.C. (3d) 464

Interview of Dr. Helen Ward, November 2006.

Interview of Criminal Defence Lawyer, November 2006.

Interview with Member of Ministry of Health and Long-Term Care, November 2006.

Interview with Wendy Stewart, October 2006.

James, D. "Court Diversion in Perspective" (2006) 40 Australian and New Zealand Journal of Psychiatry 529 at 529.

Kesey, K. One Flew Over the Cuckoo's Nest. (New York: The Viking Press New York, 1962).

Lamb. R \& L. Weinberger, Deinstitutionalization: Promises and Problems (San Francisco: John Wiley \& Sons Inc., 1994).

Latimer, E. "Community Based Care for People with Severe Mental Illness in Canada" 28 International Journal of Law and Psychiatry. 561 - 573.

Livingston, J. et. al. “A Follow-Up Study of Persons Found Not Criminally Responsible on Account of Mental Disorder in British Columbia" (2003) 48 Canadian Journal of Psychiatry. 408.

Lowman, J., R.J. Menzies \& T.S. Palys, Transcarceration : Essays in the Sociology of Social Control (England: Gower Publishing, 1987).

MacNamara, D.J. “The Medical Model in Corrections: Requiescat in Pace” (1977) 14 Criminology. 439.

Martin's Annual Criminal Code (Aurora: Canada Law Book inc., 2001).

McMahon, M. The Persistent Prison. (Toronto: University of Toronto Press, 1992). 
"Mental Illness Glossary" online: Canadian Mental Health Association $<$ http://www.cmha.ca/bins/content page.asp?cid=3-424\&lang=1 > retrieved: November $19,2006$.

Ministry of Community and Social Services. (1987) Challenges and Opportunities: Community Living for People with Developmental Handicaps. Toronto: Queen's Printer for Ontario.

Ministry of Health and Long Term Care

$<$ http://ogov.newswire.ca/ontario/GPOE/2005/01/12/c2146.html $>$.

Minkoff, M. "Program Components of a comprehensive system for seriously mentally ill patients with substance abuse disorders." New Directions for Mental Health Services, 91 (2001). 17 at 31 .

Mitchell, S. Ottawa Court Police Liasion Office. Ottawa, Ontario, January to September 2006.

Moore, D. [unpublished]

Newman, D. “2000 and Beyond: Strengthening Ontario's Mental Health System” (1998) online: Ministry of Health and Long Term Care

$<$ http://www.health.gov.on.ca/english/public/pub/mental/mentalreform.html >.

Nolan, J Reinventing justice: The American drug court movement (Princeton: Princeton University Press, 2001) at 254.

Nolan, J. The Therapeutic state; Justifying Government at Century's End (New York: York University, 1998).

Obagi, J. \& E. Quiqley, "Mental Health Assessments - Jailing the Mentally Ill Pending Assessment" (2006) Ottawa 1-9.

Obagi, J. "Victims of Section 672.11" online: Cooligan \& Ryan $<\mathrm{http}: / / \mathrm{www}$. cooliganryan.com/victims.cfm>.

Olfman, S. Diagnosis, Drugs, and Bipolar Disorder in Children (Westport: Prager Publishers, 2006).

Ontario Council on Health "Agenda for Action: Report of the Committee on Mental Health Services in Ontario" (Toronto: Ontario Ministry of Health, 1979).

Ontario Ministry of Community and Social Services. Challenges and Opportunities: Community Living for People with Developmental Handicaps (Toronto: Queen's Printer for Ontario, 1987). 
Ontario Public Service Employees Union (OPSEU) January 13, 2006 “Re-Announced Funding Does little to keep mental health patients out of jail"

Ontario Forensic Mental Health Bed Registry Ministry of Health and Long-term Care. Online: http://www.bedregistry.com/ 2006.

Phaneuf v. Her Majesty the Queen in Right of Ontario, Statement of Claim: 16 January, 2006.

Phelan, J. and B. Link. "The Growing belief that people with mental illnesses are violent: the role of the dangerousness criterion for civil commitment" 33 Journal of Social Psychiatry.

Pinet v. Penetanguishene Mental Health Centre [2006] O.J. No. 678 (Ont Sup Ct).

"Putting People First: The Reform of Mental Health Services in Ontario" (The Ministry of Health; 1993) online: Canadian Mental Health Association $<$ http://www.ontario.cmha.ca/docs/system/puttingpeoplefirst.pdf $>$.

Rope of Silicon online: <http://www.ropeofsilicon.com/movies.php?id=1687> retrieved November 16, 2006.

Rothman, D. The Discovery of the Asylum (Boston: Little Brown, 1971).

Royal Ottawa Healthcare Group online: http://www.rohcg.on.ca/resources/glossarye.cfm?strSearch=manic found January 15, 2007.

Rupert, J. "Beds not Jail for Mentally Ill" The Ottawa Citizen (5 May 2005) online: Proquest. $<$ http://proquest.umi.com. $>$.

Rupert, J. "Mentally Ill Jailed Despite Judges Order" The Ottawa Citizen. May 27, 2005.

Rupert, J. "Mentally Ill Still Being Illegally Jailed"(3 November 2005). online: Proquest. $<$ http://proquest.umi.com. $>$.

Her Majesty the Queen v. Rosete and Centre for Addiction and Mental Health. 2006. Appellant's Factum.

R v. Cooper [1980] 1 S.C.R. 1149 (S.C.C.).

R v. Hussein and Dwornik [2004] 191 C.C.C. (3d) 113 (O.S.C.J)

R v. Kurd. [2005] O.J. No. 2794.

R v. Madden (1977) 35 C.C.C. (2d) 381(Ont. H.C.J.) 
R v. Olsen [1989] 1 S.C.R. 296

R v. R.L.L. [2004] O.J. No. 3604 (Ont. Sup. Ct).

R v. Rosete, [2006] O.J. No. 1608

R v. Swain [1991] S.C.R. No. 933

Scull, A. Decarceration: Community Treatment and the Deviant - A Radical Review. (New Jersey: Englewood Cliffs; 1977).

Shah, S.A. \& B. D. Sales, Eds. "The criminalization hypothesis: Myth, misnomer, or management strategy" Law and Mental Health: major developments and Research Needs (United States; Rockville, 2001).

Siebenmorgen, E. “Assessment Orders Under Part XX.I of the Criminal Code: The Current Environment" (Toronto: April 2006) at 5.

Smart, B. Michel Foucault (London: Routledge Press, 1991).

Statement of Claim Phaneuf v. Her Majesty the Queen in Right of Ontario January 16, 2006.

Statistics Canada Mental Health Statistics (1983) Vol. III Institutional Facilities Services and Finances 1980-1981.

Steadman, H.J., et al., The Mentally Ill in Jail (New York: Guilford; 1987).

Teplin, L. (1991). The criminalization hypothesis: Myth, misnomer, or management strategy. In S. A. Shah \& B. D. Sales (Eds.), Law and Mental Health: major developments and Research Needs (pp. 149-183). Rockville, MD: US Department of Health and Human Services.

The Time has Come: Making it Happen. A Mental Health Action Plan for Toronto and Peel. Final Report to the Ministry of Health. December 2002

The Roeher Institute. Research Issues in Evaluating Deinstitutionalization. November 6, 1995.

Verdun-Jones, S. "The Insanity Defence in Canada: Setting a New Course" (1994) 17 International Journal of Law and Psychiatry 175.

Vitelli, R., "The homeless inmate in a maximum-security prison setting." Canadian Journal of Criminology, 35. (1993). 323-331. 
Zapf, P. et. al. "Have the Courts Abdicated Their Responsibility for Determination of Competency to Stand Trial to Clinicians?" (2004) 4 Journal of Forensic Psychology Practice 27 at 44.

Zapf, P.A., R. Roesch, \& S.D. Hart., "An examination of the relationship of homelessness to mental disorder, criminal behavior, and health care in a pretrial jail population." Canadian Journal of Psychiatry, 41. (1996). 435-440. 


\section{Appendices}




\section{Appendix A:}

\section{List of Acronyms}

CMHA - Canadian Mental Health Association NCRMD - Not Criminally Responsible on Account of Mental Disorder HSRCU - Health System's Research and Consulting Unit

CAMH - Centre for Addiction and Mental Health ACTT - Assertive Community Treatment Teams ROMHC - Royal Ottawa Mental Health Centre MOHLTC - Ministry of Health and Long-term Care OPSEU - Ontario Public Service Employees Union MOH - Ministry of Health MCSCS - Ministry of Community Safety and Correctional Services OTIS - Offender Tracking Information System 


\section{Appendix B:}

\section{List of Interviews}

Name

1. Wendy Stewart

2.

3. Dr. Helen Ward

4.

5.

\section{Position}

Professional Social Worker

Member of the Ministry of Health and Long Term Care

Forensic Psychiatrist and Clinical Director of the Forensics service Program at the Royal Ottawa Mental Health Centre

Criminal Defence Lawyer

Lawyer

\section{Date}

October, 2006

November, 2006

November, 2006

October, 2006

October, 2006 


\section{Appendix C:}

\section{Informed Consent Form}

Supervisor: Professor Dawn Moore

Carleton University

Tel: $613-520-2600$ ext 3823
Researcher: Krista Lazette

Carleton University

Master of Legal Studies Student

Tel: 613-594-8840

The purpose of this research project will be to explore the current crises at the interface of the criminal justice system and the mental health system. This research is undertaken to fulfill the thesis requirement of the Master of Legal Studies Program at Carleton University. agree to participate in this research project.

- I agree that my participation in this research project is voluntary and will involve answering questions relating to my professional knowledge and/or working capacity with accused mentally ill.

- I agree to meet with the researcher once, in person or by telephone, to answer questions about this topic.

- The interview will take an hour.

- I understand that I am being interviewed in my professional capacity and therefore face minimal risk.

- I I agree to be audio taped.

- I I I do agree not to be audio taped, only notes may be taken.

- I may terminate the interview at any time. Should I exercise my right to withdraw I will decide at that time if the information I have provided to that point may be used or request that it be destroyed.

- I am also informed that the work will be published and thus accessible to the general public, my co-workers and employers.

- I understand that my Consent form will be kept in a locked filing cabinet in Krista Lazette's home and only she and her supervisor, Professor Dawn Moore will have access to the forms, interview material and that interview transcripts, tapes and notes will be stored electronically. I understand that although Krista Lazette's computer will have the necessary security hardware I cannot guarantee that the information I provide will be secure. 
- The data will be destroyed ten years (2017) after the research is completed using paper shredders for information on paper and electronically deleting files stored electronically.

I understand that I may contact Professor Antonio Gualtieri, Chair of the Ethics Committee, with any ethics concerns or complaints.

Carleton University

Tel: $613-520-2517$

Signature of Participant

Date:

Signature of Researcher

Date: 


\section{Appendix D:}

\section{Letter of Information}

Supervisor: Professor Dawn Moore

Carleton University

Tel: 613-520-2600 ext 3823

Department of Law

C473 Loeb

1125 Colonel By Drive, Ottawa, ON

K1S 5B6

Research Ethics Committee Coordinator

511A Tory Carleton University

Tel: 613-520-2517
Researcher: Krista Lazette

Carleton University

Master of Legal Studies Program

Tel: 613-594-8840

\section{Dear Sir/Madame:}

The purpose of this research project will be to explore the current crises at the interface of the criminal justice system and the mental health system. This research is undertaken to fulfill the thesis requirement of the Master of Legal Studies Program at Carleton University.

In order to explore the procedures and policies of dealing with accused mentally ill who have encountered the criminal justice system I will interview Ottawa court Psychiatrists, Psychologists, Lawyers, Crown Attorney's, Judges, Justices of the Peace, Social Workers, mental health court outreach workers, individuals involved in developing policy relating to the interface of the mental health system and the criminal justice system and correctional staff at the Regional Carleton Detention Centre.

I would like to request an hour of your time to ask you questions about your experiences, involvement and knowledge of the practices and procedures of dealing with mentally ill individuals who have come into conflict with the criminal justice system.

If time is critical I would be happy to conduct the interview by telephone. If you would prefer to have the questions sent to you by fax I would be happy to accommodate you.

If we are able to meet for a face to face interview it would be at our time and convenience. I would also like your permission to audio record the interview for the purposes of accuracy. I will transcribe the interviews. If you do not wish to be recorded then I will only take notes.

You may decline answering any questions and can withdraw your agreement to participate in the interview at any time and have the data withdrawn. Should you decide 
to withdraw you may decide at that point if I may use any portion of your interview or request to have the notes and tapes destroyed immediately.

You will not directly benefit from this research. This research will begin to address the current crisis of mentally ill individuals in conflict with the criminal justice system.

Interview notes, tapes, and consent forms will be kept in a locked filing cabinet in my home. Interview transcripts and notes will be stored electronically. Although my computer will have the necessary security hardware I cannot guarantee that the documents stored electronically will be secure. Only I and my supervisor Dr. Dawn Moore will have access to these materials. The data will be destroyed ten years (2017) after the research is completed using paper shredders for information on paper and electronically deleting files stored electronically.

This research will be disseminated through conference papers, workshops, classroom presentations and possibly peer reviewed journal articles.

This project has been reviewed and received ethics clearance through the Carleton University Research Ethics Committee and if you have any questions or concerns regarding your involvement you may contact the ethics committee.

The chair's information is as follows:

Prof. Antonio Gualtieri, Chair

Carleton University Research Ethics Committee

Carleton University 1125 Colonel By Drive

Ottawa, Ontario K1S 5B6

Tel: 613-520-2517

E-mail: ethics@carleton.ca

Krista Lazette

Professor Dawn Moore 


\title{
Appendix E
}

\author{
FORM 48
}

(Section 672.13)

\section{ASSESSMENT ORDER}

\section{Canada, Province of \\ (territorial division)}

Whereas I have reasonable grounds to believe that evidence of the mental condition of (name of accused), who has been charged with ...., may be necessary to determine*

_ whether the accused is unfit to stand trial

- whether the accused suffered from a mental disorder so as to exempt the accused from criminal responsibility by virtue of subsection 16(1) of the Criminal Code at the time of the act or omission charged against the accused

- whether the accused is a dangerous mentally disordered accused under section 672.65 of the Criminal Code

- whether the balance of the mind of the accused was disturbed at the time of commission of the alleged offence, where the accused is a female person charged with an offence arising out of the death of her newly-born child

- where a verdict of unfit to stand trial or a verdict of not criminally responsible on account of mental disorder has been rendered in respect of the accused, the appropriate disposition to be made in respect of the accused pursuant to section 672.54 or 672.58 of the Criminal Code

_ where the accused has been convicted of the offence, whether an order under subsection 747.1(1) of the Criminal Code should be made in respect of the accused

I hereby order an assessment of the mental condition of (name of accused) to be conducted by/at (name of person or service by whom or place where assessment is to be made) for a period of days.

This order is to be in force for a total of the accused is to remain* days, including travelling time, during which time

_ in custody at (place where accused is to be detained)

_ out of custody, on the following conditions:

(set out conditions, where applicable)

* Check applicable option.

Dated this day of A.D. ....., at

(Signature of justice or judge or clerk of the court, as the case may be) 


\section{Appendix F}

FORM 48.1

(Section 672.13)

ASSESSMENT ORDER OF THE REVIEW BOARD

Canada,

Province of

(territorial division)

Whereas I have reasonable grounds to believe that evidence of the mental condition of (name of accused), who has been charged with ...., may be necessary to ${ }^{*}$

[ ] if a verdict of unfit to stand trial or a verdict of not criminally responsible on account of mental disorder has been rendered in respect of the accused, make a disposition under section 672.54 of the Criminal Code

[ ] if a verdict of unfit to stand trial has been rendered in respect of the accused, determine whether the Review Board should make a recommendation to the court that has jurisdiction in respect of the offence charged against the accused to hold an inquiry to determine whether a stay of proceedings should be ordered in accordance with section 672.851 of the Criminal Code

I hereby order an assessment of the mental condition of (name of accused) to be conducted by/at (name of person or service by whom or place where assessment is to be made) for a period of .................... days.

This order is to be in force for a total of days, including travelling time, during which time the accused is to remain ${ }^{*}$

[ ] in custody at (place where accused is to be detained)

[ ] out of custody, on the following conditions:

(set out conditions, if applicable)

${ }^{*}$ Check applicable option.

Dated this day of A.D. , at

(Signature of Chairperson

of the Review Board) 


\section{Appendix G}

\section{Interview Questions ${ }^{280}$}

1. What is your professional capacity in working directly or indirectly with individuals suffering from mental health problems?

2. How long have you been working in this capacity?

3. What do your professional responsibilities include?

4. Are you aware of any new developments (whether policy or legal) within the criminal justice system impacting mentally ill individuals?

4. How many beds are available for individuals who are court ordered for a psychiatric assessment at the Royal Ottawa Hospital?

5. When an individual has been ordered for an in-custody psychiatric assessment which level of security would he/she be detained under while under-going the assessment?

6. Are you aware of major developments (either policy or legal) that have had an effect on practices at the Royal Ottawa Hospital?

7. I understand that there will be less bed space at the new Royal Ottawa Mental Health Centre Hospital. Will the forensic unit be affected by this move? How many beds are there currently at the Royal Ottawa Hospital? How many beds are they loosing in the move?

8. What is the legal bearing of the expert opinion of a court psychiatrist in determining whether the assessment should take place in-custody or out of custody?

\footnotetext{
${ }^{280}$ It should be noted that the interviews were open ended and questions changed depending on whom I spoke with.
} 